\title{
LEASE CHATTEL PAPER: UNITARY TREATMENT OF A "SPECIAL" KIND OF COMMERCIAL SPECIALTY $\dagger$
}

\author{
Amelia H. Boss*
}

At the time of its adoption thirty five years ago the Uniform Commercial Code revolutionized the law of secured transactions. ${ }^{1}$ Article 9 on secured transactions codified parts of the existing law, but it also introduced new rules and an extensive new body of nomenclature. The drafters of the Code coined the term "chattel paper"2 to denote a new commercial specialty subject to special rules concerning the creation of a security interest, ${ }^{3}$ its perfection, ${ }^{4}$ the abililty of the obligor on the paper to raise defenses against a subsequent assignee, ${ }^{5}$ and the validity of

$\dagger$ (c) 1983 by Amelia H. Boss.

- Assistant Professor of Law, Rutgers, The State University of New Jersey, School of Law, Camden, New Jersey.

1. See, e.g., Gilmore, The Secured Transactions Article of the Commercial Code, 16 Law \& CONTEMP. ProBs. 27, 28 (1951) (departure from prior law "radical"); Gilmore, Article 9: What it Does for the Past, 26 LA. L. REv. 285 (1966) ("revolutionary") [hereinafter cited as Gilmore, Article 9]. But see 1 G. Gilmore, Securtty Interests in Personal Property $\$ 10.2$ at 299 (1965) (discussion of the "conservative, traditional nature of Article") [hereinafter cited as G. Gilmore, SeCurity InTERests]. See generally Beutel, The Proposed Uniform Commercial Code as a Problem in Codification, 16 LAW \& ConTeMP. Probs. 141 (1951); Coogan, Relationship of Article 9 of the Uniform Commercial Code 10 Pre-Code Chattel Security Law, 51 VA. L. REv. 853 (1965); Robinson \& Marsh, Some Observations on Article 9 of the Uniform Commercial Code, 63 Dick. L. Rev. 45 (1958); Spivak, Amending the Uniform Commercial Code; A Report on Valid Critlcism and Suggested Change-In re Article 9, 28 TEMP. L.Q. 603 (1955).

2. Section $9-105(l)(b)$ defines chattel paper as follows:

(b) "Chattel paper" means a writing or writings which evidence both a monetary obligation and a security interest in or a lease of specific goods, but a charter or other contract involving the use or hire of a vessel is not chattel paper. When a transaction is evidenced both by such a security agreement or a lease and by an instrument or a series of instruments, the group of writings taken together constitutes chattel paper.

U.C.C. $\$ 9-105(1)$ (b) (1978) (unless otherwise noted, all citations to the Uniform Commercial Code are to the 1978 Official Text).

3. Section 9-203(1)(a) eliminates the necessity of a writing to satisfy the statute of frauds when chattel paper is in the hands of the secured party.

4. A security interest in chattel paper nuay be perfected either by filing, U.C.C. $\$ 9-304(1)$, or by possession, id. $\$ 9-305$, although a secured party with a possessory security interest has greater protection under certain circumstances. See id. §9-308 and discussion infra notes 175-85 and accompanying text.

5. See U.C.C. $\$ \$ 9-206(1), 9-318$. During the drafting of Article 9, section 9-206 underwent substantial revision stemming in part from disagreement as to the dcgree of negotiability of chattel paper under the Code. Negotiability determines whether a transfer of chattel paper will cut off defenses that the account debtor could otherwise assert against the account creditor. See, e.g., Bautista \& Kennedy, The Imputed Negotiability of Security Interests Under the Code, 38 IND. L.J. 
the security interest against the claims of a good faith purchaser of the paper. ${ }^{6}$

This article examines the Code's treatment of lease chattel paper, which is a lease transferred by the lessor to a financer as collateral for a loan or in an outright sale. It also examines the recurrence on the finance level of the distinction between true leases and security leases. Under a true lease, the lessor retains a meaningful economic interest in the leased goods, ${ }^{7}$ but a security lease is no more than a disguised conditional sales contract. ${ }^{8}$ With the proliferation of various forms of leasing, ${ }^{9}$ it has becoune increasingly difficult to distinguish between true leases and security leases. ${ }^{10}$ This confusion, exacerbated by the growth

574 (1963); Kripke, Chattel Paper as a Negotiable Specialty Under the Uniform Commercial Code, 59 YALE L.J. 1209, 1214-22 (1950) [hereinafter cited as Kripke, Chattel Paper]; see also infra notes $134-45$ and accompanying text.

6. See U.C.C. \& 9-308.

7. See Coogan \& Boss, Uniform Commercial Code Treatment for all Leases, reprinted in [1982] P. Coogan, W. Hogan \& D. Vagts, 1 Secured Transactions under U.C.C. (MB) $\$$ 4.3.01-.03. A true lease inerely transfers possession of the leased item, which the lessee is obligated to return. A true lease of personalty has traditionally been classified as a bailment at common law. See infra notes 21-24 and accompanying text.

8. In a conditional sales contract, the seller retains title to the goods to secure payment of the full purchase price; at payinent title passes to the buycr. Attempts to avoid the laws goveming conditional sales led to the use of disguised conditional sales contracts in which the seller characterized the transaction in lease language. The problem of distinguishing bailments for hire (true leases) from conditional sales or security leases dates from Justice Story's time. See R. Brown, The Law of Personal Property \$\$ 9.1, 10.1 (3d ed. 1975); J. Story, Commentarues on the LAW OF BAILMENTS $\$ 371$ (6th ed. 1856).

9. See generally T. A. Ison \& S.P. Amembal, The Handbook of Leasing: Techniques AND ANALYSIS 19-54 (1982); Shapiro, The ABC's of Leasing, 1972 U. ILL. L.F. 433, 434-36.

10. The dividing line between a true lease and a security lease is a fine one, and the distinction has been extensively debated in several contexts. There was a large amount of litigation under the pre-Code conditional sales statutes, see $3 \mathrm{~L}$. Jones, Chattel Mortgages and Condtional Sales $\$ 952-76$ (Bowers ed. 1933); 2 S. Williston, A Treatise on the Law of ConTRACTs $\$ 336$ at $697-710$ (3d ed. 1959), and one commentator traces the problem back to Hervey v. Rhode Island Locomotive Works, 93 U.S. 664 (1876), see Claxton, Lease or Security Interest: A Classic Problem of Commercial Law, 28 MERCER L. REv. 599, 601-02 (1977).

Cases decided under the Code have grappled with the distinction between the two types of leases in determining whether Article 2 on sales applies to a transaction. See, e.g., Chatlos Sys. v. National Cash Register Corp., 479 F. Supp. 738 (D.N.J. 1979), affd, 670 F.2d 1304 (3d Cir. 1982), cert. dismissed, 102 S. Ct. 2918 (1982); Citicorp Leasing v. Allied Institutional Distribs., 454 F. Supp. 511 (W. D. Okla. 1977). See generally Abrams, The Diminishing Difference Berween Selling and Leasing Tangible Personal Property, 24 VILL. L. REv. 706, 712-21 (1979) (examining the consequences of the sale-lease distinction in the Article 2 areas of implied warranty, unconscionability, and the related non-Code area of strict liability in tort); Farnsworth, Implied Warranties of Quality in Non-Sales Cases, 57 CoLUM. L. Rev. 653, 655-60 (1957).

The debate also arises in determining whether Article 9 applies. See Coogan, Leases of Equipment and Some Other Unconventional Security Devices: An Analysis of UCC Section 1-201(37) and Article 9, 1973 DUKE L.J. 909, updated in [1982] I SECURED TRANSACTIONS UNDER U.C.C. (MB) \$ 4A.01-.08;.DeKoven, Proceedings After Default by the Lessee Under a True Lease of Equipment in [1982] P. COOOAN, W. HOGAN \& D. VAGTS, I SECURED TRANSACTIONS UNDER U.C.C. (MB) 
of the leasing industry, ${ }^{11}$ has provoked debate over whether the distinction should be eliminated and unitary treatment accorded all leases. ${ }^{12}$ The proposed codification of leasing law ${ }^{13}$ makes the question especially timely.

The debate usually occurs in discussions of the rights or remedies

88 29.B.01-.09; Hawkland, The Impact of the Uniform Commercial Code on Equipment Leasing, 1972 U. IL. L.F. 447; Leary, Leasing and Other Techniques of Financing Equipment Under the U.C.C. 42 TEMPLE L.Q. 217 (1969); Mooney, True Lease or "Intended as Security"-Treatment by the Courts in [1982] P. COOGAN, W. HoGAN \& D. VAGTs, 1 Secured TRANSActions under U.C.C. (MB) 88 29.01-.07; Peden, The Treatment of Equipment Leases as Security Agreements Under the Uniform Commercial Code, 13 WM. \& MARY L. REv. 110 (1971); Stroh, Peripheral Security Interests-The Expanded Net of Aricle 9, 22 U. MLAmI L. REv. 67 (1967). Similarly, a lessor's ability to reclaim the leased goods at the lessee's bankruptcy depends on whether the transaction was a true lease or a disguised conditional sale. Burke, Bank Counsel's Guide to Equipment Leasing Transactions: Nontax Aspects, 94 BankING L.J. 580, $599-600$ (1977); Fogel, Executory Contracts and Unexpired Leases in the Bankruptcy Code, 64 MrNN. L. REv. 341, 347-51 (1980); Hawkland, supra at 455-57; Heller, Security Aspects of Chattel Leases in Bankruptcy, 34 FORDHAM L. REV. 439, 447-50 (1966); see also infra note 14.

11. In the thirty-five years since the adoption of the Uniform Commercial Code, the leasing business has grown explosively and now represents a sizable sector of our econony. The growth rate of the equipinent leasing industry has exceeded thirty percent per annum several times during the past two decades. J. Campanel la, Leveraged Lease Financing and the Commercial BANK 5 (1974). By 1980, the total original cost of industrial equipment on lease in the United States was $\$ 150$ billion, Verespe, Why Doesn't Inflation Hurt Leasing, INDUSTRY WEEK, Dec. 8, 1980 , at 39, and the value of equipment leases executed in that year alone was approximately $\$ 37$ billion. Faster Write-Offs May Spur Leasing, Bus. WeEK, March 23, 1981, at 95-96. The American Association of Equipment Lessors projected that by 1985 there will be $\$ 200$ billion in outstanding contracts worldwide. Moskel, Equipment Leasing: A Recession Option, INDUSTRY WEEK, Sept. 3, 1979, at 94, 95. Approximately one-third of all new equipment accepted for delivery in the United States goes into use through leasing. Leasing Offers Many Advantages, 79 Credir AND Fin. MGMT., Jan. 1977, at 34.

12. Compare Kripke, Book Review, 37 Bus. LAw. 723, 727, 729 (1981) (the distinction between true leases and security leases is insignificant and should be abandoned) with Coogan, Is There A Difference Between a Long.Term Lease and an Installment Sale of Personal Property?, 56 N.Y.U. L. REv. 1036, 1059 (1981) (distinction between the two types of leases is essential). One solution would be to carve out a new (or third) type of leasing transaction and nake it sui generis, subject to an entirely new set of rules. See Leary, The Procrustean Bed of Finance Leasing, 56 N.Y.U. L. REV. 1061 (1981); UNIFORM RULES ON THE SUI GENERIS FORM OF LEASING TRANSACTION, Study LLX, DOC. 13 (Preliminary Draft 1981, International Institute for the Unification of Private Lsw (UNIDROIT) Study Group) [hereinafter cited as UNIDROIT], reprinted in [1982] P. COOGAN, W. Hogan \& D. VAGTS, 1 SECURED TRANSACTIONS UNDER U.C.C. (MB) \$ 4.1.03-.04. In the alternative, Article 9 could be amended to cover all true leases. See Coogan \& Boss, supra note $7,884.3 .02,4.3 .04$.

13. In 1980, the American Bar Association formed the Subcommittee on Personal Property Leasing to explore the possibility of uniform codification of the rules of personal property leasing. See Mooney, Personal Property Leasing: A Challenge, 36 Bus. LAw. 1605 (1981). More recently, the National Conference of Commissioners on Uniform State Laws appointed two reporters to explore the codification of personal property leasing law. See Coogan \& Boss, supra note 7, \& 4.3. On the international level, the International Institute for the Unification of Private Law formed a study group in 1975 to undertake the task of drafting inodel rules applicable to the international leasing of personal property. See UNIDROIT, supra note 12; see also Boss, Products Liability and International Leasing Transactions: The UNIDROIT Drafi Convention, I J. PROD. L. 143 (1982). 
of the parties to the immediate lease transaction. ${ }^{14}$ This article, however, focuses on the transfer of the lease in a subsequent finance transaction. ${ }^{15}$ These transactions are subject to the Code's chattel paper rules, which inandate unitary treatment for true leases and security leases. Theoretically, true leases should have been included in the Code's definition of an account. ${ }^{16}$ The drafters' preoccupation with covering disguised conditional sales in the Code suggests that these security leases were the drafters' primary concern, and that true leases may have been included in the chattel paper definition more by inadvertence than by design. ${ }^{17}$ Consequently, true leases have acquired some of the characteristics of a quasi-negotiable commercial specialty. ${ }^{18}$ Nevertheless, the need to provide commercial certainty to financers who have no means of knowing whether a lease is a true lease or a security lease justifies the Code's unitary treatment of true and security leases.

At several points, however, the Code's purported unitary treatment bifurcates, and the distinction between true and security leases reemerges. Some of these bifurcations are trivial flaws caused by the drafters' preoccupation with security leases. These minor bifurcations can be easily corrected by a slight amendment to the Code or by a liberal reading of its present language. Other bifurcations are major; they result from the inherent differences between true leases and secur-

14. For example, various commentators have argued that the filing requirements of Article 9 should apply to all or most leases. See, e.g., Hawkland, The Proposed Amendments 10 Article 9 of the UCC-Part 5: Consignments and Equipment Leases, 77 CoM. L.J. 108 (1972); Leary, supra note 12; Peden, supra note 10; Note, Recording Equipment Leases: A Proposed Amendment 10 the Uniform Commercial Code, 47 Notre DaMe Law. 993 (1972); Comment, Selected Problems in California Chattel Leasing: Equipment Leasing Under the U.C.C., 13 U.C.L.A. L. REV. 125 (1965). But see Coogan, supra note 10.

The distinction between true leases and security leases is also important in determining the parties' rights on default, see Coogan, supra note 10, at 1045-55; DeKoven, supra note 10, $\$$ 29B.03, 29B.06.

15. It must be emphasized that uniess the confusion between true and security leases is resolved at the level of the underlying lease transaction, it will recur at the level of the financing transaction and may cause problems for an assignee who attempts to enforce the lease against a lessee or its trustee in bankruptcy. These problems, however, are not peculiar to the finance transaction; inherent to the underlying lease transaction, they are outside the scope of this article. See Coogan \& Boss, supra note 7, $\$ \$ 4.3 .02,4.3 .04$ for a possible resolution of some of these issues at the lease level.

16. See infra notes $96-107$ and accompanying text.

17. See infra notes $90-95$ and accompanying text.

18. The "entire thrust and purpose of the Code's treatunent of security in chattel paper is to assimilate it to a "commercial specialty, i.c., negotiable instruments." Levie, Security Interests in Chattel Paper, 78 YALE L.J. 935, 939 (1969), reprinted with minor changes in [1982] P. CoOOAN, W. Hogan \& D. Vagts, IC Secured TRansactions under U.C.C. (MB) $\$ 828,28.02-.05$. [hereinafter cited by author and section number in SECURED TRANSACTIONS UNDER U.C.C.]. See also infra notes 90-107, 132-33 and accompanying text. 
ity leases. These major bifurcations can be remedied only by a modification of the non-Code attributes of true leases. Unfortunately, this remedy would seriously thwart the expectations of parties to lease transactions. This article concludes that, although unitary treatnent may be desirable because it obviates the distimction between true and security leases, the policy of uniformity nuay not always outweigh the policy of protecting the legitimate expectations of the parties. Thus, although the chattel paper rules create serious problems in some situations, these problems cannot be remedied under the Code's current format.

\section{Chattel Leases Under Non-Code Law}

The historical distinction between a true lease and a security lease, in particular the difference between the rights each represents and the manner in which those rights are transferred, resurfaces continually in Article 9. Although non-Code law provides the backdrop against which Article 9 must be evaluated, ${ }^{19}$ the law that governs leases of personal property never achieved the sophisticated developinent characteristic of the law of realty leases. ${ }^{20}$ The dearth of adjudicated cases dealing with bailments ${ }^{21}$ in general ${ }^{22}$ and personal property leases in particular ${ }^{23}$ illustrates the lack of refinement in the old common law. ${ }^{24}$ Despite the paucity of cases, however, general principles of bailment

19. According to Grant Gilmore, the chief drafter of Article 9, the Code "assumes the continuing existence of a large body of pre-Code law and non-Code law on which it rests for support, which it displaces to the least possible extent, and without which it cannot survive. The solid stuff of pre-Code law will furnish the rationale of decisions quite as often as the Code's own gossamer substance." Gilmore, Article 9, supra note 1, at 286.

The term "pre-Code" law is appropriate in describing that body of law existing prior to the adoption of the Uniform Commercial Code; the term "non-Code" law is broader, encompassing both pre-Code law and that body of law outside of but coexistent with the Code.

20. See Theiss, Security Aspects of Equipment Leasing, 1962 U. ILL. L.F. 77 (personal property lease is a "legal misfit").

21. The common law of bailments governed all chattel transactions in which the owner parted with possession but not with title. A bailment is "a delivery of a thing in trust for some special object or purpose, and upon a contract express or implied, to conform to the object or purpose of the contract." J. STORY, supra note $8, \$ 2$.

22. The general definition encompassed such divergent transactions as the pledge, the entrusting of goods to a carrier for delivery or to a warehouseman for storage, delivery for purposes of repair, gratuitous loans of items to another, and chattel leases. Some of these transactions are now governed by discrete bodies of law. For example, the Uniform Commercial Code now governs the law of pledges in Article 9, and the law of warehousing and carrier contracts in Article 7.

23. The lease was characterized as a "bailment for hire," defined as a bailment where compensation is to be given for the use of an object, or for labor on or services to it. J. STORY, supra note $8, \S 368$. It falls into the subcategory of locatio rei in which the bailee pays compensation for its use. Id.

24. See DeKoven, Enforcement of the Equipment Leases: The Bankruptcy Code in EQuIPMENT LeAsino-Leveraged Leasing (B. Fitch \& A. Reisman eds. 1981); W. Jones, AN EsSAY 
may aid in construing the modern chiattel lease and in understanding the problems that its assignment causes.

\section{A. The Rights That a Chattel Lease Represents.}

Bailment law contemplates the separation of the right to possession of the chattel from the right to its ownership or title. In bailment vernacular, the bailor during the period of the bailment retains the general or absolute property right im the chattel while the bailee acquires merely a "special property" right. ${ }^{25}$ Despite the initial failure of personal property law to recognize expectant estates or future estates im personalty or chattels, ${ }^{26}$ the law eventually recognized a reversionary interest in the bailor. ${ }^{27}$

When an owner of an item leases it to another, the owner parts with the right to the present possession, use, and enjoyment of the item. The property rights ${ }^{28}$ that the lessor retains may imclude: the future right to the leased chattel on termination of the lease (the lessor's rever-

ON THE LAW OF BaILMENTS 2 (1781); DeKoven, supra note 10, \$29B.05; Siegel, Is the Modern Lease a Contract or a Conveyance?-A Historical Inquiry, 52 J. URB. L. 649, 674-75 (1975).

Most of the existing bailment law doctrines are directly traceable to Roman law, R. BROWN, supra note $8,8 \S 10.1,11.1$, and do not adequately address the modem leasing transaction. Thus, despite the admomition that bailment law should be deternimative precedent for chattel leasing cases, see DeKoven, Leases of Equipment: Puritan Leasing Co. v. August: $A$ Dangerous Decision, 12 U. SAN FrAN. L. REv. 257, $279-80$ (1978), the law provides little guidance.

25. J. STORY, supra note $8, \S 373$.

26. English law considered the ownership of personal property to be indivisible. See $3 \mathrm{~W}$. Holdsworth, A History of the English Law 89 (1923); J. Vaines, Personal Property 39 (1954); J. Willlams, Principles of the law of Personal Property 71 (2d Amer. ed. 1855). Despite the parallels between land law and chattel law, in ancient times the doctrines of expectant estates had no application to personal property. See J. DarLINGTON, A Treatise on the LaW of Personal Property $\$ 33$ (1891); 1 J. Schouler, A Treatise on the LaW of Personal Property \& 136 (5th ed. 1918) [hereinafter cited as J. Schouler, Personal Property].

27. The law protected this interest by allowing bailors to recover for damage to the goods in the possession of the bailee. See generally $3 \mathrm{~W}$. HoldsworTH, supra note 26, at 337; 0 . W. Holmes, The Common law 165-66 (1923); 2 F. Pollock \& W. Maitland, The History of English LaW Before the Time of Edward I 155-56; J. Schouler, The LaW of Bailments, INCluding Pledge, InNkeefers aNd Carriers $\$ 39$ (2d ed. 1887) [heremafter cited as J. Schouler, Batlments]; Bordwell, Interests in Chattels Real and Personal, 1 Mo. L. Rev. 119 , 124-25 (1936). The law also limited the bailee's ability to pass title of the goods to a third party. See generally R. BROWN, supra note $8, \$ \$ 9.3,10.5,11.9$; J. STORY, supra note $8, \& 394$.

28. Although these rights are arguably the natural incidents of the lessor's basic right to ownership of the leased chattel, several of them arise from the lease agreement. For example, the lease agreement creates and defines the right to rentals because the existence of the agreement distinguishes the lease transfer from a gift or a theft. Similarly, the lease contract creates the right to repossess and the right to the benefits of covenants in the lease. Such rights would not exist in the absence of a lease; yet they are also natural incidents of ownership, because they allow the owner to protect its interest in property. This dual nature of the lessor's rights makes it difficult to describe what happens when "the lease," as opposed to the ownership of the property, is transferred. 
sionary interest); 29 the present title to the chattel, less the present right to the possession and use of it; ${ }^{30}$ the right to rents or profits under the lease of the item; the right to repossess the item on default of the lessee; the right to prevent misuse of the leased chattel; ${ }^{31}$ and the benefit of other covenants in the lease. ${ }^{32}$

A lessor under pre-Code law could always convey its interest in the leased goods themselves ${ }^{33}$ or assign its rentals ${ }^{34}$ in return for financmg. ${ }^{35}$ If it chose instead to "assign the lease," 36 it was extremely un-

29. The lessor's expectation of future possession of the leased goods is called a "reversion" by analogy to real property law, even though technically the lessor's ownership interest continues throughout the lease term.

30. The right to present title and the right to future possession and title on expiration of the lease are conceptually different and distinct proprietary rights. For example, the holder of the present title has an insurable interest even if he has no right to future possession because he has a legal or enforceable right or alternatively because he has a factual expectation of loss. See $\mathbf{R}$. KeEton, Basic TeXt ON INSURANCE \$ 3.2(g) (1971).

31. See J. VAINes, supra note 26 , at $43-44$.

32. These covenants could include options to purchase or covenants restricting the use of property. Corbin has described these types of covenants as the "jural relations that accompany an assignable right." 4 A. CORBIN, CoRbin ON CONTRACTS; A Comprehensive TREATISE ON THE RULES OF CONTRACT LAW $\S 878$, at 525 (1951). Although there has been little litigation on the question, in thcory it is possible for the owner of a right to sever it from its accompanying powers, privileges, and immunities and to assign it separately. Id.

If a covenant in the lease gives the lessor a security interest in other personal property of the lessee to secure the rental obligation, see, e.g., Gold Coast Leasing Co. v. California Carrots, Inc., 93 Cal. App. 3d 274, 278-79, 155 Cal. Rptr. 511, 514-15 (1979) (lessor granted security interest in contracts and accounts receivable), the chattel paper would qualify as both lease chattel paper and security chattel paper.

33. The typical statement is that the bailor may, subject to the bailee's rights, sell, mortgage, or encumber its right, title, and interest in the property bailed. See P. VAN ZILE, ELEMENTS OF the Law of Bailments and Carriers, Including Pledge and Pawn and InNkeepers § 21 (2d ed. 1908); see also, e.g., Clark v. Williams, 190 Mass. 219, 76 N.E. 723 (1906).

34. See, eg., Vadner v. Rozzelle, 88 Utah 162, 45 P.2d 561 (1935).

The drawback of an assignment of rents as a security device is that it inay be unenforceable. The financer may always bring suit if the lessee defaults, but the financer has no independent means of forcing payment without the lessor's cooperation. Without an explicit assignment of the lease, it is not clear that the assignee could repossess the leased property or take other action on default. Moreover, the financer runs the risk that the lessee will assert his defenses against the lessor in any action on the rental covenant. See Restatement (SECOND) of CONTRACTs $\& 168$ (1981).

35. In rare cases, the lessor may assign any of the other covenants or powers contained in the lease. See supra note 32 . The right to repossess and sell goods (the "raw power") may possibly be assigned; the few cases on point have sustained the assignments despite arguments that a chattel mortgage was created. See McGriff v. Porter, 5 Fla. 373 (1853) (grant of power to enter, seize, and dispose of property not coupled or connected with any interest in the property is not a mortgage); Shaw v. Silloway, 145 Mass. 503, 14 N.E. 783 (1888) (the grant of power to sell goods on debtor's default and apply proceeds to outstanding loan does not transfer legal title to creditor, creating a mortgage; nor does it create a hen); Holmes v. Hall, 8 Mich. 66 (1860) (grant of power to surety to take immediate possession of debtor's property and to sell it to pay for debt and surety's service does not convey title to property and is not a mortgage, lien, or pledge, but "is nothing but a naked power not coupled with any prescnt interest"). But see Hurd v. Brown, 37 Mich. 484 (1877) (con- 
clear what interests it had conveyed. ${ }^{37}$ It was clear, however, that a lessor of chattels could transfer its proprietary interest or reversionary interest in the leased chattels and that this assignment would carry with it the right to receive rentals. ${ }^{38}$ Alternatively, the lessor could sever the right to rentals from the reversionary interest by separate transfers of the reversion and of the right to rentals under the lease agreenent. ${ }^{39}$ Thus, assignment of the rentals or the lease does not necessarily convey the owner's reversionary interest, ${ }^{40}$ which exists outside and independently of the lease. ${ }^{41}$ The lease represents the lessor's grant of the use and possession of the leased property, the lessee's covenant to pay rent,

tract of indemnity is a mortgage). For a more modern case involving the assignment of lessor's rights on default, see In re New Mexico Ice Mach. Co., 32 U.C.C. REP. SERv. (Callaghan) 1647 (Bankr. D.N.M. 1981) (assignee's rights under assigned default clause subject to security interest in leased goods).

36. Under real property law an assignment by the lessor, rather than by the lessee, should not technically be called an "assignment of the lease." United States v. Shafto, 246 F.2d 338, 342 (4th Cir. 1957); Penn Gardens Section Two v. Melnick, 256 Md. 72, 77, 259 A.2d 520, 523 (1969). Nevertheless, this is the accepted manner of speaking.

It should be noted that under non-Code law the lessor may assign the true lease without transferring the written lease document itself; thus oral leases, although not the subject of this article, may be assigned. It is likewise true that a third party does not acquire the rights that the true lease represents (rentals and ancillary covenants) merely by acquiring physical possession of the lease document. Handing over the lease document is not comparable to livery of seisin since the lease document does not embody the rights the lease represents, but merely describes them. See infra notes 64-68 and accompanying text.

37. Professor Corbin has criticized the phrase "assignment of the contract" on the grounds that the complex legal relations created by a contract must be analyzed individually to determine which have been transferred in a particular assignment of the contract. See 4 A. CoRBIN, supra note $32, \S 864$.

38. If the transfer was an outright sale of the lessor's interest in the equipment without reservation, the transferee acquired the immediate right to collect rent. Feldman v. Philadelphia Nat'1 Bank, 408 F. Supp. 24, 40 (E.D. Pa. 1976).

39. See In re Isaacson, [1895] I Q.B. 333. The right transferred is the right to rentals accruing after the date of the assignment. See, e.g., Pendall v. Eells, 97 Mich. 657, 35 N.W. 754 (1888).

40. See Vadner v. Rozzelle, 88 Utah 162, 45 P.2d 561 (1935) (assignment of lease does not transfer title to the original property); In Re Isaacson, [1895] 1 Q.B. 333 (assignment of reversion transfers proprietary rights, and assignment of leasing agreement transfers contractual rights); In re Davis Co., [1888] 22 Q.B.D. 193 (lessor's assignment of "all right and interest" in the leasing agreement does not confer on the assignee any property interest in the goods); see also Feldman v. Philadelphia Nat'l Bank, 408 F. Supp. 24, 34-35 (E.D. Pa. 1976) (49 U.S.C. 81403 does not require recording of airplane lease assignments because no title or interest in property is affected by the assignment, and ownership interest is not transferred); Feldinan v. Chase Manhattan Bank, 368 F. Supp. 1327 (S.D.N.Y. 1974), rev'd on other grounds, 511 F.2d 468 (2d Cir. 1975) (the assignment of a lease transfers "its primary incident, the right to receive rentals").

41. Some comnientators have imcorrectly stated that a lease assignment inay be attacked as an unrecorded chattel mortgage of the lessor's imterest in the leased equipment. See Comment, Acquisition of Industrial \& Commercial Equipment Through Leasing Arrangements, 66 YALE L.J. 751,766 \& ri.73 (1957). If the "assignment" of a true lease is an outright sale, however, nothing is mortgaged, and if the lease is assigned as security, only the right to rentals (plus perhaps some ancillary covenants) is transferred. See Booth v. Kehoe, 71 N.Y. 341 (1877). Cf. Alford v. Marten, 176 S.C. 207, 180 S.E. 13 (1935) (recording of a "mortgage on a mortgage" held unnecessary 
and other ancillary covenants. Apart from covenants by the lessee to return the property in good repair, nothing in the lease refers to or creates the lessor's reversion. ${ }^{42}$

To a great extent, determining which of the lessor's rights in addition to the right to rentals have been transferred when the lease is assigned depends on the intention of the parties. ${ }^{43}$ If the parties' intent is not evident, there is considerable confusion as to what the assignment transfers. 44 The right to the goods on termination of the lease and the present right to ownership of the goods, collectively the "reversionary interest," do not pass; but assignment of the lease may possibly transfer the lessor's right to repossess and the benefits of other covenants in the

to give notice to assignee where he purchased mortgages on goods at thirty-five percent of face value); Woodward v. Laporte, 70 Vt. 399, 402, 41 A. 443, 444 (1898).

In several chattel cases, the lessor's assignee of a lease has attempted to claim returned or repossessed goods, only to be met with the successful defense that the assignee's failure to take possession of the goods or otherwise perfect its interest in the returned goods gave rise to a fraudulent secret lien. See, eg., Truck, Tractor, \& Forwarding Co. v. Baker, 281 Pa. 145, 148-49, 126 A. 239, 240-41 (1924). Although these cases implicitly assume that a lessor's assignee could claim the goods, the theory behind this claim was never developed. The assignee's claim may arise under the default provisions of the assigned contract, or the returned goods may be considered proceeds of the assigned lease. In either event, the assignee's claim to returned or repossessed goods is independent of an assignment of the reversion.

42. The authorities erroneously cite other cases for the proposition that assignment of the lease is synonymous with a transfer of the reversion. See, eg., $1 \mathrm{H}$. TIFFANY, A TREATISE ON THE LAW OF LANDLORD AND TENANT, $8146 \mathrm{~b}$ (1912). The cases are easily distinguishable. Several involved assignments by lessees who had sublet the premises, rather than assignments by lessors, who retained the reversion. See, eg., Root v. Burgess, 8 Cal. 2d 27, 63 P.2d 293 (1936); Patten v. Deshon, 67 Mass. (1 Gray) 325 (1854). Others contain incomplete factual statements. See, e.g., Merchant's State Bank of Fargo v. Ruettell, 12 N.D. 519,97 N.W. 853 (1903) (headnotes add facts showing right of possession transferred). Other cases simply involve the lessor's agreement not to encumber or convey property. See, eg., Tahoe Nat. Bank v. Phillips, 92 Cal. Rptr. 704, 480 P.2d 320 (1971); Coast Bank v. Minderhout, 61 Cal. 2d 311, 38 Cal. Rptr. 505, 392 P.2d 265 (1964).

The only case actually holding that an assignment of "all my right, title and interest in and to a certain indenture of lease" transferred the lessor's interest in the premises can be explained as an atteinpt to bring the assignee within the protective coverage of a statute which would give the assignee the right to distrain for rent. See Keely Brewing Co. v. Mason, 102 III. App. 381 (1902).

43. See Restatement (SECOND) OF CoNTRACTs 8 317(1) (1981).

United States v. Shaflo, 246 F.2d 338 (4th Cir. 1957), provides a good illustration of how a court will look at the actions of the parties to determine what rights they intended to transfer by assigning the lease. In Shafto a husband who assigned some leases to his wife claimed that he thereby transferred the reversion and was not the owner of the property. The court concluded otherwise because the husband had agreed to make improvements on the property and, during the terms of the leases, took deductions for repairs, depreciation, insurance, and taxes.

44. Early cases support the distinction between rights under the lease and the simple right to rentals, but they do not suggest what besides rentals an assignment of the lease transfers. See White v. Kane, 53 Mo. App. 300 (1893) (either in law or equity an assignment of rents is not necessarily an assignment of the lease which secures the rents); Demarest v. Willard, 8 Cow. 206 (N.Y. 1828) (an express agreement that assigns the right to collect rents transfers only the right to the rents as they accrue, while assignment of the lease transfers all the lessor's right and title under it). 
lease. Under general contract principles the assignee of the chose in action also acquires all incidental rights and remedies to which the assignor was entitled.45 Covenants designed to preserve the leased chattel, such as the covenants to keep the goods in working order, to insure them, and to return thein at the end of the lease, are intended to protect the lessor's reversionary interest and are incidental to that interest. ${ }^{46}$ Covenants designed to protect the right to the payment of money, such as provisions for late charges, acceleration, and hquidated damages on early termination, should be construed as incidental to the rents and should pass to the assignee of the lease..$^{47}$

This analysis applies only to the assignment of a true lease, however. The transfer at common law of a chattel mortgage ${ }^{48}$ or conditional sales contract $^{49}$ normally transferred to the assignee the assignor's property interest in the chattel as well as the right to pay-

45. 4 A. Corbin, supra note 32, \& 878; Restatement of Contracts $\$ 171(2)$ (1932); 3 S. Williston, supra note $10,8432 \mathrm{~A}$. In the case of a debt, the primary "incidental right," and the right most often at issue, is the security given for that debt. See 4 A. Corbin, supra note 32, 8907. Other incidental rights include the right to bring suit to collect the debt or the right to discharge the debt. Id. $\$ 878$.

46. There are no cases applying the general contract principle to lease transfers. Real property law provides guidance, however, because it uses a similar analysis to determine which covenants in a lease of realty run with the rentals and which run with the reversion.

47. One troublesome covenant is the right to regain possession of the chattels on default of the lessee. As late as 1937 one treatise writer termed this right a personal license that could not be assigned. See L. GoOdeve, Modern LAw OF Personal. Property 64 (8th ed. 1937) (citing In re Davis \& Co. 22 Q.B.D. 193 (1888)). But see Truck, Tractor, \& Forwarding Co. v. Baker, 281 Pa. 145, 126 A. 239 (1924) (assignee of lease could claim benefit of default provision if he acted within a reasonable time). The assignee of the lease should be able to claim any repossessed or returned goods on the grounds that the default provisions are covenants designed to protect the stream of rental payments or that the returned items constitute "proceeds" of the lease. See supra note 28.

48. An assignment by the chattel mortgagee of all his interest in a mortgage was an assignment of the secured debt, 2 L. JONES, supra note $10, \S 502$, and transferred all the rights of the mortgagee to the assignee. Greenspan v. Ehrlich, 277 IIl. App. 322 (1934); Riley v. Washington, 161 So. 896 (La. Ct. App. 1935). On the other hand, an assignment of the secured debt transferred all the mortgagee's equitable interest in the mortgaged property whether the assignment was before or after forfeiture. 2 L. JoNES, supre note 10,8503 . After the assignment of the debt the chattel mortgagee becames a mere trustee of the legal title with no power to release or discharge the mortgage. Id. $\& 503 \mathrm{a}$.

49. The transfer by the seller of a conditional sales contract as security for a debt should vest all the conditional vendor's rights, title, and interest in the assignee. $3 \mathrm{~L}$. JoNEs, supra note 10, 8 1253. This was the general rule if the transfer was an outright sale. Id \& 1244. See also Worcester Morris Plan Co. v. Mader, 236 Mass. 435, 128 N.E. 777 (1920); Rapp v. Mabbett Motor Car Co., 201 A.D. 283, 194 N.Y.S. 200 (1922); People's Nat'l Bank v. Brunelle, 101 Vt. 42, 140 A. 160 (1928); Moreliouse v. Spokane Sec. Fin. Corp., 175 Wash. 501, 27 P.2d 697 (1933). Some courts, however, took the opposite view when the assignment was for security purposes only; they held that the assignee took inerely the right to collect the money and had no right upon vendee's default to realize upon the property itself. 3 L. JoNES, supra note 10, \& 1253; see Bank of Cal. v. Danamiller, 125 Wash. 255, 215 P. 321 (1923) (assignment for security of conditional sales contract transfers no right to property on default). 
ments under the contract, ${ }^{50}$ just as the contemporary assignee of a note secured under a security agreement acquires all the rights of the assignor under the security agreement. ${ }^{51}$ These principles follow the general rule that in the absence of a provision to the contrary, the assignment of a claim (to installment payments, for example) transfers both the claim itself, and the underlying seeurity. ${ }^{52}$ Thus, there is a fundamental distinction between the interests transferred by the assignment of a true lease and the interests transferred by the assignment of a security lease. The assignment of a true lease transfers primarily the right to rentals and their ancillary covenants, but not the right to the reversion. The assignment of a security lease transfers both the right to rentals and the reversion, with their respective covenants.

\section{B. Transfer of a Chattel Lease.}

Choses in action are by definition intangible and are therefore incapable of the physical dehivery and possession necessary for the assignment, gift, or pledge of personal property. ${ }^{53}$ Early cases, however, recognized that certain choses in action represented by writings ${ }^{54}$ could be assigned by transfer of the document because business practice and the law merchant treated the writing as an embodiment of the obligation itself;:s the obligation was transferred by delivery of the instrument, which was surrendered to the obligor when the obligation was

S0. See Worcester Morris Plan Co. v. Mader, 236 Mass. 435, 128 N.E. 777 (1920); State Bank of Black Diamond v. Johnson, 104 Wash. 550, 177 P. 340 (1918). But see Clark, Bankers' Guide to UCC Filing Problems-Loans for Equipment Leasing, 92 BANKING L.J. 222, 229 \& n.6 (1975) [hereinafter cited as Clark, Bankers' Guide].

51. Quaranto v. Silverman, 345 Mass. 423, 187 N.E.2d 859 (1963).

52. R. Brown, supra note $8,815.6$, at $485 ; 4$ A. CoRBIN, supra note 32,8907 , at 633; RESTATEMENT OF SECURTY 829 (1941); see, eg., Waterburg Trust Co. v. Weisman, 94 Conn. 210, 108 A. 550 (1919) (assignment of purchase money notes also transfers conditional bill of sale of goods).

53. "Choses in action" inust be distinguished from "choses in possession." The latter refers to rights in definite tangible things over which possession may be asserted; the former refers to property rights which, though they may be represented by a piece of paper such as a promissory note, are essentially jintangible in that they can be claimed or enforced only by legal action, not by physical possession. See Holdsworth, The History of the Treatment of Choses in Action by the Common Law, 33 Harv. L. Rev. 997 (1920); see also 4 A. CoRBIN, supro note 32, 8 859, at 416 (disapproving of the term "choses in action").

54. Choses in action that traditionally have been recognized as being ennbodied in a document include negotiable instruments, money, bills of lading, warehouse receipts, and stock certificates. Such documents are often subject to rules which, strictly speaking, apply only to tangible personal property. See R. BRown, supra note 8, 8 1.7, at 12.

55. With the revival of trade in the seventeenth century, bills of exchange were introduced in England's mercantile community. There, custoin rendered thein negotiable and legally capable of assignment or transfer by simple endorsement or delivery of the writing. J. CHITTY ON BILL * 10 . In the same manner, promissory notes became assignable by endorsement and delivery during the reign of Queen Anne. 4 \& 5 Anne, ch. 16 (1705) (repealed). See J. Schouler, Personal Prop- 
satisfied. ${ }^{56}$ Other choses in action were originally not assignable because they were not represented by such an instruinent.s7 Even when the law began to recognize the assignability of this second type of chose, the transfer of a writing evidencing the chose was insufficient to transfer the claim; a written assignment was necessary. ${ }^{58}$

The traditional requireinent, then, was that in order to be capable of delivery, a chose in action had to be represented by an indispensable, or symbolic, writing. This was the requirement when the Code was enacted. ${ }^{59}$ Since that time, the non-Code requirenent has been relaxed and liberalized; under the inore liberal approach, virtually any written contract inay be transferred by delivery of the document or evidentiary writing. ${ }^{60}$ With the possible limited exception of chattel paper, ${ }^{61}$ however, the Code recognizes only the pledge of those choses in action that

ERTY, supra note $26, \S 72$, at 9i-92; Holdsworth, supra note 53 , at 1027. "Negotiable" originally meant that the claim was transferable by transfer of the writing.

56. Under traditional non-Code law, the mere existence of a document purporting to evidence a chose in action did not make the document representative of the obligation. Instead, the document or writing had to meet a certain standard. Various formulations of the requirement exist: the Restatement of Security requires an indispensable instrument so representing the intangible that enjoyment, transfer, or enforceinent of the intangible depends upon possession of the instrument. RESTATEMENT OF SECURITY \& I and comment e (1941). The first Restatement of Contracts requires a symbolic writing, that is, a "tangible token or writing, the surrender of which is required by the obligor's contract for its enforcement. . ." Restatement of ConTrActs $\S \S 158(1)(b), 170(3), 173(b)(i v)$ (1932).

57. See R. BROWN, supra note $8, \S 8.2$, at 156 .

58. See id. at 156-59.

59. When the first Restatement of Contracts was drafted, Professor Bruton argued for recognition of delivery of evidentiary writings, written documents in which the obligation is set out and to which the parties could first look for proof of the obligation. Bruton, The Requirement of Delivery as Applied to Gifts of Choses in Action, 39 YALE L.J. 837 (1930); see also 4 A. Corbin, supra note 32, \$919. Professor Bruton's view did not prevail; the Restatement's chief reporter leapt to the draft's defense, and the stricter formulation appeared in the first Restatement. Williston, Giffs of Rights Under Contracts in Writing by Delivery of the Writing, 40 YALE L.J. 1 (1930).

60. The second Restatement of Contracts reflects the modern, liberalized approach and recognizes that there may be manual delivery of a cliose in action by delivery of an evidentiary writing, as well as by delivery of a symbolic writing. See RESTATEMENT (SECOND) OF CONIRACTs \& 332(1)(b) comment $c$ (1981). The second Restatement defines an evidentiary writing as "a writing of a type customarily accepted as a symbol or as evidence of the right assigned." Id. $\$ 332(1)(b)$.

61. Article 9 does not recognize possessory interests in every contract evidenced by a writing, but only in those that fall within the definition of an instrument, document, or chattel paper. See U.C.C. $\S 9-305$. The second Restatement of Contracts, in adopting the more liberal approach of recognizing evidentiary writings as well as symbolic writings, nevertheless classifies chattel paper in the symbolic category. See RESTATEMENT (SECOND) OF CoNTRACTS \& 332 comment c (1981). The Article 9 drafters apparently also believed that chattel paper was a symbolic document. See U.C.C. \& 9-103 comment 5(a) (accounts and general intangibles not represented by an "indispensable or symbolic document which represents the underlying claim, whose endorsement or delivery is the one effectual means of transfer"). The second Restatement accepts the apparent conclusion of the drafters of Article 9 that chattel paper in "the regular course of business [is] treated as adequately evidencing that a person in possession of the writing is entitled to receive 
were traditionally embodied in a symbolic document, ${ }^{62}$ and does not recognize the pledge of evidentiary writings. ${ }^{63}$

Given the ramifications of finding a symbolic writing, ${ }^{64}$ it is surprising that the issue of whether a lease document is a symbolic writing has not been extensively litigated. Although soine commentators liave asserted that leases can be pledged, ${ }^{65}$ the cases they cite do not support the position that the written document is an indispensable writing such that its plysical transfer creates a pledge; 66 the cases support the conclusion that the term "pledge" is often used in improper and confusing ways. ${ }^{67}$ On the other liand, there are cases that hold that the inere

performance and to dispose of the right and its proceeds." Restatement (SECOND) OF CONTRACTS \& 332 comment c (1981).

62. According to the drafters, choses that fall within the definition of an instrument, a document, or chattel paper, see U.C.C. \& 9-305, are unique:

in contemplation of law and by common understanding and practice the property right

or claim evidencing an instrument, document or chattel paper is thought of as being

merged in or symbolically represented by the piece of paper, whose endorsement or de-

livery is a prerequisite to a transfer of the underlying claim of right.

U.C.C. \$ 9-103 comment 2 (1962).

63. Both Restatements of Contracts rely on the facts of In re Higgins, $204 \mathrm{~Pa} .167,53 \mathrm{~A} .746$ (1902), involving delivery of a written contract containing coal rights. The first Restatement concluded that the gift was not complete and was revocable. RestatemENT OF CONTRACTs \& 158, illustration 2 (1932). The second Restatement reacles the opposite conclusion. RESTATEMENT (SECOND) of CoNTRACTs \& 332, illustration 5 (1981). Under the Code, the contract rights would be classified as accounts, and could not be pledged. The definition of chattel paper, unlike the definition of instrument or document, does not contain language that expressly makes the category open-ended. G. GILMORE, SECURITY INTERESTS, supra note 1, \& 12.5, at 379.

64. Whether a chose in action is represented by a symbolic writing determines whether delivery of the writing makes a gratuitous assignment irrevocable. See, e.g., RESTATEMENT OF CONTRACTS \& 158 (1932). It also determines which of two successive assignees has priority, see, e.g., RESTATEMENT OF CONTRACTS \& 173(b)(iv) (1932), whether the obligor's performance discharges it from a duty to the assignee, see id. 8170 , whether the chose in action may be pledged, see RESTATEMENT OF SECURITY \& 1 and comments a, c \& 2(3) and comment b (1941), and other issues, see, eg., Booth v. Kehoe, 71 N.Y. 341 (1877) (creation of a pledge may determine whether retention of the document by the assignor is presumptive of fraud).

65. J. SCHOULER, BAILMENTS, supra note 27, 8 143, at $75 \mathrm{n} .1$ (1905); J. Schouler, PERSONAL Property, supra note 26, § 395, at 589; Annot., 53 A.L.R. 2d 1396, 1410 (1957).

66. Although many issues seemed to turn on whether a transfer was a pledge or a mortgage, the "courts never devised a workable rule for making [that] distinction." 1 G. GILMORE, SECURITY INTERESTS, supra note $1, \$ 1-1$, at 7 . This led to a "built-in ambiguity in many of the discussions whether certain kinds of intangibles [could] be pledged." Id. 81.2 , at 10. For purposes of this article, the term "pledge" means that the "possession of some writing by the creditor will give him an interest in the rights represented by it which cannot be defeated by any interest subsequently created by the pledgor." Id. \& 1.3, at 12-13 (footnote omitted). The term "pledge" is not always so restricted, however. See infra note 67 and accompanying text.

67. The carliest case cited is Dewey v. Bowman, 8 Cal. 145 (1857), overruled on other grounds, Gagliardo v. Hoberlin, $18 \mathrm{Cal} .394$ (1861). The court in Dewey never addressed the question of whether physical possession of a lease was a pledge; it focused instead on the remedies of an assignee on default. Similarly, in Ringling v. Smith River Dev. Co., 48 Mont. 467, 476, 138 P. 1098,1099 (1914), when the court announced in dictum that "[t]he authorities seem quite uniform in holding that a lcase of, or mortgage upon, real estate may be pledged," the court did not mean 
physical transfer of the lease document has no effect. ${ }^{68}$

By contrast, non-Code law generally considered conditional sales contracts or chattel mortgages as capable of pledge by dehivery. ${ }^{69}$ Such agreements are usually accompanied by promissory notes, ${ }^{70}$ and the negotiability of the note may be imputed to the accompanymg security agreement. The imputation of negotiability gives the holder of the written agreement the right to enforce the agreement. ${ }^{71}$ Hence, delivery of the writing was necessary to protect the security assignee from claims of subsequent assignees, ${ }^{72}$ and the assignment of a conditional

that a lease obligation may be transferred by possession of the lease document. It simply concluded that the law of personalty (pledges) rather than the law of realty (mortgages) governed the assignment of a contract for the sale of realty.

In Gem State Lumber Co. v. Galion Irrigated Land Co., 55 Idaho 314, 41 P.2d 620 (1935), the documents evidenced both the lease of realty and a security interest in crops. Relying at least in part upon the fact that the documents had been filed in the office of the county recorder, as required by law, and that therefore they could not be physically transferred, the court found that the nonpossessory assignment of a lease of realty was a valid assignment of a cliose in action and not a pledge, thus implying that possession of the lease document is not necessary to transfer the interests it evidences. Id at 324-25, 41 P.2d at 624. On the other hand, in State Bank v. Jennings, 78 Misc. 524, 138 N.Y. 606 (Sup. Ct. 1912), the lessee's assignee who was second in time but was in possession of the lease document was allowed to prevail over a prior assignee not in possession, despite New York's first-in-time rule, on the theory that the first assignee's lack of possession gave rise to the defenses of laches or estoppel. Id. at 528, 138 N.Y.S. at 608. It is arguable that Jennings does not apply to cases involving assignment by chattel lessors. In Jennings, the lessee assigned her real estate leasehold but remained in possession of the leased premises; therefore, possession of the lease document was the only reliable means of discovering or identifying an assignee. But see 4 A. CORBIN, supra note 32, $\$ 902$, at 619 (citing Jennings as illustration of Restatement of Contracts \& 173, under which failure to take possession of formal document may give rise to estoppel).

68. In Bordereaux v. Walker, 85 Ill. App. 86 (1899), the court held that the lessor could not be reinvested with legal title to the lease by redelivery of the lease document. Id. at 89 . In Booth v. Kelioe, 71 N.Y. 341 (1877), the court upheld the lessee's assignment of the leasehold even though the assignee was not in possession of either the lease or the premises.

69. 2 L. JONES, supra note 10, \&518 ("nonproduction of these instruments [mortgage] by the unortgagee is a suspicious circumstance, and is sufficient to put the debtor upon imquiry"); see, e.g., Baxter v. Gilber, 12 Abb. Pr. 97, 100-01 (N.Y.C.P. 1861); R-F Fin. Corp. v. Summers, 168 Okia. 179, 181-84, 32 P.2d 312, 314-18 (1934) (filing of chattel mortgage held to serve as constructive notice to third party); see also In re Nizolek Furniture \& Carpet Co., Accrs. REc. FIN. SERv. (PH) \& 33,011, affd, 7I F. Supp. 1012 (D.N.J. 1947), affd, 165 F.2d 788 (3d Cir.), cert. denied, 334 U.S. 816 (1948) (upholding assignment of chattel paper on grounds it was for present consideration); Citizens' Inv. Co. v. Starr Piano Co., 128 Or. 1, 273 P. 387 (1929); Schumann v. Bank of Cal., 114 Or. 336, 233 P. 860 (1925).

70. See also Kripke, Chattel Paper, supra note 5, at 1225. When the UCC was drafted, it was a commercial practice to use this type of chattel paper as security. See Adelson, The Mechanics of the Installment Credit Sale, 2 LAw \& Contemp. ProBs. 218 (1935); Kripke, The "Secured Transactions" Provisions of the Uniform Commercial Code, 35 VA. L. REv. 577,597 (1949).

71. See Bautista \& Kennedy, supra note 5, at 576. Bur see Kripke, Chattel Paper, supra note 5 , at 1220 (argnments against imputed negotiability).

72. Citizens' Inv. Co. v. Starr Piano Co., 128 Or. 1, 273 P. 387 (1929); Schumann v. Bank of Cal, I14 Or. 336, 233 P. 860 (1925). 
sales contract was often excluded from the coverage of accounts receivable statutes. ${ }^{73}$

The treatment and nature of leases under non-Code law makes it clear that traditionally leases were very different from chattel mortgages or conditional sales. The lease primarily represented the right to payment of money and did not represent any reversionary interest such that transfer of the lease would transfer an interest in the leased goods. By contrast, conditional sales contracts and chattel mortgages did represent an interest in the goods. Moreover, although a lease document never acquired the status of a symbolic writing capable of delivery, conditional sales contracts and chattel mortgages did achieve that status, and those interests were transferable by conveyance of the contract or mortgage. ${ }^{74}$

\section{The Lease as Collateral Under Article 9}

Once true leases and security leases are assigned as collateral, the Code treats them as if they were the same type of document and gives them, as chattel paper, some of the characteristics of a negotiable instrument. True leases, however, are not at all like negotiable instruments. In some cases, the efficiency and predictability of unitary treatment warrant this departure from non-Code law. In other cases, the deviation from tradition is too radical because unitary treatment may defeat the expectations of the parties to the financing transactions.

\section{A. The Structure of Lease Financing.}

Lease financing 75 is the second step in a two-step transaction. First, the lessor transfers the right to use and possess the goods under an ordinary lease, which is sometimes represented by a lease document. The lessor then assigns the lease to a financer, in a second and distinct transaction to which Article 9 applies. ${ }^{76}$ In Code parlance, the lessor-

73. See, eg., CONN. GEN. STAT. \&6718 (1949) (repealed 1961) (excluding conditional sales contracts and others which were traditionally assigned "by endorsement on or delivery of the instrument"); ILL. ANN. STAT. ch. 1211/2, \& 220 (Smith-Hurd 1960) (repealed 1962) (excluding accounts represented by a document "the surrender of which is required by the obligor's contract . . . for the enforcement thereof"); PA. Stat. ANn. tit. 69, $\$ 561$ (Purdon Supp. 1968) (repealed 1953); TeX. Crv. Stat. an. 260-1, \& 1(1)(b) (Vernon 1948) (repealed 1965). All statutes of this kind were repealed by the enactment of the U.C.C.

74. See supra note 36.

75. The term "lease financing" as used in this article refers to the use of a lease as collateral for a loan. The term in other contexts can also refer to the acquisition of equipinent by lease rather than by purchase. See generally Leary, supra note 12, at 1061-62, 1065-66.

76. In some cases, however, U.C.C. \&9-104(f) may exclude the assignment froin Article 9 coverage. 
assignor is the "debtor;" "7 the financer-assignee is the "secured party;"78 and the lessee in the underlying lease transaction, who is obligated to make rental payments, is the "account debtor."

When a lease is assigned by the lessor to a third party, the assignment transaction can take any of numerous forms. ${ }^{80}$ The assignment inay be part of an outright sale of the lease in return for operating capital. Although the parties may not intend to create a security interest, Article 9 governs this transaction because it applies to "any sale of chattel paper,"81 and leases generally fit the definition of chattel paper. $^{82}$ The drafters included sales of chattel paper in Article 9 because these sales, like secured loans, are a form of commercial financing, ${ }^{83}$ and often the sale of chattel paper is indistimguishable from its assignment as security. ${ }^{84}$ The assignment may also be inade to secure "payment or performance of an obligation," 85 as is the case if the lessor assigns the lease to a creditor as collateral for a loan. This transaction is intended to create a security interest and is also covered by Article 9.86 Some assignments of leases, which do not perforn financing functions, are excluded from the scope of Article 9.87

77. "Debtor" means "the person who owes payment or other performance of the obligation secured . . . and includes the seller of accounts or chattel paper." Id. $\S 9-105(1)(d)$.

78. "Secured party" means "a lender, seller or other person in whose favor there is a security interest, including a person to whom accounts or chattel paper have been sold." Id. \$9-105(1)(m).

79. "Account debtor" means "the person who is obligated on an account, chattel paper or general intangible." Id. §9-105(1)(a).

80. See, e.g., Burke, supra note 10; Gutterman; Equipment Leases as Collateral Under the UCC and the New Bankrupicy Code, 12 U.C.C. L.J. 344 (1980); Riordan \& Duffy, Lease Financing: A Discussion of Security and Other Considerations from the Institutional Lender's Point of View, 24 BUS. LAW. 763 (1969); Shane, Bank Equipment Leasing: How to Improve Documents and Procedures, 96 BANKING L.J. 485 (1979).

81. U.C.C. $\$ 9-102(1)(b)$.

82. See infra notes 114-21 and accompanying text. As a result, the sale of a lease is governed by the perfection, priority, and default provisions of Article 9.

83. See U.C.C. $\$ 9-102$ introductory comment and colnunent 2 . If the documents are ambiguous, it is a question of fact whether the parties intended an outright sale or an assignment for security. Lucius Beebe \& Sons v. Wason, 274 Mass. 254, 174 N.E. 500 (1931); 4 A. Corain, supra note 32, $\$ 881$.

Although Article 9 covers both a sale and a security assignment of a lease, it does not treat the two identically. See U.C.C. \$ 9-502 (rights of a secured party on collection). To avoid usury laws, transactions historically have been cast as "sales" with full recourse rather than as assignments for security. See West Pico Furniture Co. v. Pacific Fin., 2 Cal.3d 594, 86 Cal. Rptr. 793, 469 P.2d 665 (1970).

84. See U.C.C. $\$ 9-102$ comment 2.

85. Id. \& 1-201(37).

86. See id. \& 9-102(1)(a).

87. See id. § 9-104(f); see also Bramble Transp. v. Sam Senter Sales Inc., 294 A.2d 97, 101 (Del. Super. Ct. 1971), affd, 294 A.2d 104 (Del. 1972) (assignment of accounts receivable covered by Code when of a "financing nature"); Spurlin v. Sloan, 368 S.W.2d 314 (Ky. Ct. App. 1963) (assignment of chattel paper not covered by Code when for collection purposes only). Where the 
The lessor may use leases as security for a loan without assigning the leases, merely by creating a security interest in the rentals. ${ }^{88}$ Lessors resort to this arrangeinent when the lease term is shorter than the equipinent's useful life or when a prior indenture or agreement prohibits the lessor from selling or encumbering assets. This transaction is essentially accounts receivable financing under a basic loan agreement. ${ }^{89}$

\section{B. Unitary Treatment of Leases as Chattel. Paper.}

A conditional sale disguised as a lease is in effect a secured transaction, and it would defeat the policy of Article 9 if such transactions were excluded from its coverage. The writings of the drafters ${ }^{90}$ and the history of, ${ }^{91}$ and comments to, ${ }^{92}$ the Code clearly deinonstrate that the drafters were "more interested in refining the pre-Code 'disguised conditional sale' versus 'true lease' battle"93 by bringing the forner within the scope of Article 9 than they were in treating true leases as chattel paper. ${ }^{94}$ Professor Kripke has candidly admitted that in the drafting of section 9-105(1)(b) the drafters were not concerned with true leases but with disguised conditional sales: "[t]he reference to leases is because of

lease is transferred as part of the sale of the equipment itself, however, the transaction may be subject to Article 9 even though it is not a form of financing. See infra note 189.

Whether the lease is sold or assigned, the agreement determines the right of the secured party to proced back against the lessor-debtor in event of the lessec's default. The transaction may be with recourse, without recourse, or with limited recourse. If the document is silent as to whether there is recourse against the account creditor, the transaction is with recourse if it secures an indebtedness, and without recourse if it is an outright sale. See U.C.C. 8 9-502(2).

88. The collateral in this case may be defined as an "account." See infra notes 96-107 and accompanying text.

89. See Levie, supra note 18, at \& 28.02-.05; Levie, The Equipment Lease as Collateral in P. COOOAN, EQUIPMENT LEASINO 1976, at 275 (PLI 1976).

90. See 1 G. GLMORE, SEcurrTY INTERESTS, supra note 1, 812.5 , at 378-79 (chattel paper "might be described as a 'secured instrument" "); Kripke, Chattel Paper, supra note 5, at 1211.

91. Prior drafts show a preoccupation with disguised conditional sales. The May 1949 Draft specifically referred to "installment obligations arising out of the sale or lease of chattels, the payinent of which is secured by rights in chatteis." U.C.C. 8 7-104 (May 1949 Draft). Under that draft, the presence of a security interest was a crucial element of chattel paper. Later drafts included a delivery test for chattel paper that would have similarly included secured obligations but not true leases. See U.C.C. 8 9-105(b) comment 1 (1952 Official Draft); U.C.C. 8 8-106(4) comment 4 (October 1949 Draft). Testimony before the New York Law Revision Commission mentions chattel mortgages and conditional sales contracts as the type of collateral to which the chattel paper definition applies. See [1954] 2 N.Y. LAW REVISION COMM'N REPORT 1088 (remarks of Professor Charles Bunn) (1979).

92. See U.C.C. 8 9-101 comment; 89-102 comment 1.

93. See Leary, supra note 12 , at 1070.

94. See J. WHITE \& R. SUMmers, HANDBOOK OF THE LAW UNDER THE UNIFORM COMMERCul CODE $825-17$ (2d ed. 1980); see also W. Davenport \& D. Murray, Secured TransacTIONS 82.10 (c) (1978); R. HENSON, HANDBOOX ON SECURED TRANSACTIONS UNDER THE UNLFORM COMMERCuL CODE \& 3-5 (2d ed. 1979). 
the use of bailment leases or other forms of leases to serve essentially the same function as a conditional sales contract."95 The drafters theoretically did not need to mclude true leases in the Code definition of chattel paper but could have included thein within the definition of an account. Section 9-106 defines an account as "any right to payment for goods sold or leased . . . which is not evidenced by an instrument or chattel paper."96 The right to payment under a lease fits within this definition and is excluded only by the existence of a writing, which usually transforms it into chattel paper. However, oral leases, leases of non-specific goods or non-goods, ${ }^{97}$ and leases of vessels, give rise to accounts rather than to chattel paper. ${ }^{98}$ The explicit exclusion of vessel leases from the definition of chattel paper demonstrates that a lease could easily and properly be treated as an account. ${ }^{99}$

95. Kripke, Chattel Paper, supra note 5, at 1211.

96. U.C.C. \& 9-106.

97. See id. \&2-105(1), (2). Although the lease of "nonmovable goods" such as real estate, airspace, and intangibles such as patents and copyrights raises the same problems as chattel paper, it is outside the scope of this article. See generally Coogan, Kripke \& Weiss, The Outer Fringes of Article 9: Subordination Agreements, Security Interests in Money and Deposits, Negative Pledge Clauses, and Participation Agreements, 79 HARv. L. REv. 229 (1965), reprinted with changes in [1982] P. COOGaN, W. Hogan \& D. VaGts, 1C Secured Transactions UNDER U.C.C. (MB) \$23. A lease of intangibles, or of those things that do not qualify as specific goods, would be included in the definition of a general intangible. See U.C.C. $\$$ 9-106.

98. U.C.C. $\$ 9-105(1)(b)$ and comment $3 ; \$ 9-106$ and comment.

99. The Code specifically classifies this one type of written lease as an account rather than as chattcl paper. The definition of chattel paper in section 9-105(1)(b) excludes "a charter or other contract involving the use or hire of a vessel," and section 9-106 provides that "[a]ll rights to payment earned or uneamed" under such charters or contracts are accounts. Sonc types of vessel charters are actually service contracts and therefore are properly within the definition of an account, but other types of vessel charters are essentially leases of specific movable goods, that is, the chartered vessel. See U.C.C. \& 9-105 comment 3.

Prior to 1966, the Code did not inention vessel charters, which led one writer to criticize the application of the chattcl paper rules of Article 9 to ship charters and other contracts for the use of vessels. Deunon, Living with Article 9 of the Uniform Commercial Code (pts. 1-2), 133 N.Y.L.J., Feb. 18, 1965, at 4, col. 1; Feb. 19, 1965, at 4, col. 1 . The specific criticisms, however, apply equally to the imclusion of true leases in the definition of chattel paper. Vessel charters have the characteristics of a lease and also of a contract right, an account, and a general intangible; true leases also have these characteristics. The filing rules for chattel paper under the 1962 Code were uncertain, which made the financing of ship charters hazardous; until the chattel paper filing rules were amended in 1972, see U.C.C. \$9-103(3)(b), (4), this uncertainty was a problein for leases and chattel paper as well. Finally, charters exist in inultiple counterpart, which inakes perfection by possession problematic, leases, unlike the promissory notes which are usually part of security chattel paper, are also executed in counterpart. Kripke, Suggestions for Clarifying Article 9: Intangibles, Proceeds, and Priorities, 41 N.Y.U. L. REv. 687, 702 (1966), reprinted in [1982] P. COOGAN, W. HoOAN \& D. VAats, IC SeCUREd TRANSACtions UNDER U.C.C. $\$ \& 24 A, 24.03[5]$ [hereinafter cited to author and section number in SECURED TRANSACTIONS UNDER U.C.C.]. The Permanent Editorial Board solved these problems by expressly excluding vessel charters from the definition of chattel paper and classifying such charters first as contract rights, and finally as accounts (with the 1972 elimination of contract rights as a classification under the Code). See U.C.C. $\$ 9-106$ (1972). 
Conceptually and functionally, the assignment of a true lease resembles an account far more than it resembles chattel paper. This is demonstrated by comparing a true lease with a contract for the sale of goods. A contract for the sale of specific goods evidences a right to the payment of money and, like a security lease, passes title to the goods to the purchaser. The Code, however, excludes the contract from the definition of chattel paper unless it creates a security imterest in favor of the seller to secure payment of the sale price. ${ }^{100}$ From the viewpoint of the assignee, the true lease and the pure or unconditional installment sale contract are virtually identical in that they both evidence the right to the payment of money, which is transferred to the assignee. ${ }^{101} \mathrm{Al}-$ though the sales contract transfers title to the goods from the owner to the purchaser and the lease document does not, neither document "reserves" to the grantor any proprietary interest that is then transferred to the assignee. ${ }^{102}$ By contrast, the transfer of a security lease transfers not only the monetary obligation but the security as well. The Code treats the transfer of the right to payment under a sales contract as an account, but considers the transfer of the right to payment under a lease to be chattel paper. ${ }^{103}$

From an assignee's point of view, there is no reason to distinguish the assignment of a true lease from the assignment of an installment sales contract, which gives rise to an account. The fact that an installment sales contract passes title to the goods to the purchaser is irrelevant as far as the assignee is concerned; the assignee cares only about what is transferred to it: the right to payment and any security for that payment. Like the assignment of an installment sales contract, the assignment of a true lease transfers an unsecured right to payment. Furthermore, although a true lease may contain ancillary covenants by the lessee (for example, a covenant to preserve or maintain the collateral), an account may also include such covenants. ${ }^{104}$ In either case, transfer of the account or lease should transfer the ancillary covenants, and

It is not clear why vessel charters should be singled out in this manner. Like vessel charters, true leases could have been categorized either as chattel paper or as an account, and leases more closely resemble the latter.

100. See \& 9-105(l)(b). The security aspect of the transaction was considered the crucial element of chattel paper. See supra notes 91-95 and accompanying text; infra note 114. .

101. See infra notes 104-07 and accompanying text.

102. As stated previously, the reversion is independent of the lease. See supra notes $39-41$ and gccoinpanying text.

103. Compare U.C.C. \& 9-106 with U.C.C. \& 9-105(1)(b).

104. For example, an oral lease agreeinent is categorized as an account under U.C.C. § 9-106, yet it may include ancillary rights or covenants identical to those in a written lease, such as the right to acceleration of payments due upon default by the lessee, and restrictive covenants on use of the goods. 
filing will perfect a security interest in both the transferred account or lease and in its ancillary covenants. ${ }^{105}$ Finally, the fact that a lease is in writing does not distinguish it from an account, which nnay also be in writing. In either case, the transfer of the lease document or of the writing that evidences an account did not under non-Code law transfer any interest in the monetary obligation. ${ }^{106}$ The Code, however, departs from the common law on this point, granting chattel paper status-and thus negotiability 107 - to true leases.

The drafters made a choice. Conceptually and functionally, the assignment of a true lease resembles the assignment of an account, yet

105. Non-Code law deemed these incidental covenants to be transferred along with the chose in action. See supra notes $43-47$ and accompanying text. The 1962 Code ignored these covenants, leaving open the possibility that some rights ancillary to the payment of money might be classified as general intangibles.

Professor Kripke argued in 1966 that such rights are not "independent rights" like patents or copyrights, but are ancillary to and terminate with the payment of money. Kripke, supra note 99 , $\$ 24.02[6]$. He proposed a redefinition of general intangibles under section 9-106 to exclude rights ancillary to a monetary obligation or a security interest and to make it clear that that perfection of these rights occurs by perfection of an assignment of the monetary obligation or security interest to which they accrue. Id. $\S 24.08$.

The 1972 Official Text did not contain Professor Kripke's suggested revision. Instead, the urafters added a paragraph to the-comments to section 9.106 that stated: "Whatever perfection is required for the perfection of an assignment of the right to payment of money will also carry these ancillary rights." U.C.C. $\$ 9-106$ comment. Thus, whether the transferred monetary right is a lease or an account, transfer of the monetary right also transfers any ancillary covenants, and fling will perfect a security interest in both the transferred monetary right and in the ancillary covenants.

106. For a discussion of the non-symbolic nature of the lease document under non-Code law, see supra notes 53-67 and accompanying text. Despite the liberal formulation of the second Restatement of Contracts, under which the transfer of an evidentiary writing may transfer an account, the Code does not adopt that position. See infra notes 60-63 and accompanying text.

107. In their treatunent of intangibles, the drafters distinguished negotiable intangibles (instruments, documents, and chattel paper) and true or pure intangibles (general intangibles and accounts, including contract rights). See 1 G. GILMORE, SECURTY INTERESTS, supra note 1, \& 12.5, at 377; U.C.C. \& 9-106 comment.

Shortly before his death, Professor Gilmore observed with misgiving the tendency of the drafters to bestow attributes of negotiability upon any species of property which begins to play a large part in our econoiny. Decades after this tendency was embodied in Article 9, Professor Gilmore argued that the compelling economic reasons which gave rise to the concept of negotiability had ceased to exist by the mid-nineteenth century. See Gilmore, The Good Faith Purchase Idea and the Uniform Commercial Code: Confessions of a Repentant Draftsman, 15 GA. L. REv. 605, 620-21 (1981).

Professor Gilmore's misgivings about granting specialty status to new species of property have not inspired an anti-negotiability movenent. But see Rosenthal, Negotiability - Who Needs It?, 71 Colum. L. Rev. 375 (1971); see also Clark, Abstract Rights versus Paper Rights under Article 9 of the Uniform Commercial Code, 84 YALE L.J. 445 [hereinafter cited as Clark, Abstract Rights] (filing is a more advanced system than creation of new specialties). Such misgivings, however, are especially appropriate with respect to lease chattel paper. Although the characteristics of negotiability accorded to chattel paper may be rightly applied to security leases, they are perhaps inappropriately applied to true leases. See infra notes 122-33 and accompanying text. 
most leases are excluded from the definition of an account in Article 9. Conceptually and functionally, the assignment of a true lease is different from the assignment of a security lease, yet both are included in the Code's definition of chattel paper. The difficulty of distinguishing true leases from security leases and the need for Article 9 coverage for all secured transactions, including those which masquerade as leases, justifies this unitary treatnient. Because a financer may have no way of knowing whether a given lease is a security lease or a true lease when he makes a loan, unitary treatment affords commercial certainty and avoids needless hitigation. Once either type of lease is assigned, the Code's comments provide that "the same rules are made apphicable" to both. ${ }^{108}$

In several places in the Code, however, the buried distinction between true and security leases resurfaces and bifurcates the unitary treatment on the finance level. These disruptions of the unitary schene are of two distinct types. In some instances, the bifurcation results from an unimtentional drafting oversight, often an unfortunate choice of language resulting from the drafters' preoccupation with disguised conditional sales. This type of disruption of the unitary scheme can easily be remedied by a liberal reading of the language or by a mmor amendment. ${ }^{109}$ In other instances, however, the bifurcation occurs because the parties to the finance transaction both assume and rely on the inherent differences between true leases and security agreements, including security leases. In this type of case, to the extent that unitary treatment would seriously thwart the expectations of the parties, ${ }^{110}$ the Code's bifurcation of the unitary scheme ought not be remedied, and the difficulty of distinguishing between true leases and disguised conditional sales must be tolerated even on the finance level.

\section{Minor Bifurcations of the Unitary Scheme.}

Several provisions of Article 9 were drafted as though they were never intended to cover the assignment of a true lease as chattel paper, although there is no reason why they should not; the unfortunate language is a function of the drafters' inyopic focus on disguised conditional sales. If commercial certainty is to result from the unitary

108. U.C.C. \$ 9-206 comment 1.

109. Section 1-102(1) provides that the Code "shall be liberally construed and applied to promote its underlying purposes and policies." Although this provision may be applied to remedy the minor bifurcations of the unitary scheme, it may be preferable to make the remedy certain by amending the provisions of Article 9 that are clearly the result of drafting oversight.

110. It is true that the expectations of the parties are to a great extent a function of what the law is. When a change in the law is proposed to achieve unitary treatment, however, the benefits of the change must justify tampering with the existing legal structure. 
treatment of true and security leases on the finance level, these provisions should be liberally construed or amended. These provisions are "minor" bifurcations only because they are so easily remedied; reading these provisions literally would cause a significant and unnecessary disruption of the unitary scheme.

1. The Definition of Chattel Paper. There are three distinct types of chattel paper. ${ }^{111}$ First and most common is paper consisting of a promissory note, or other negotiable instrument that enbodies the obligation to pay money, coupled with a security agreement such as a conditional sales agreement, a chattel mortgage, or a security lease that is in effect a disguised conditional sales contract. ${ }^{112}$ The second type consists of security agreements that include a non-negotiable promise to pay money. ${ }^{113}$ Taken together, these two types of chattel paper may be called "security chattel paper." The third type of chattel paper consists of paper that does not evidence a security interest, but is a true lease of goods.114 This third category may be called "lease chattel paper."

The definition of chattel paper in section 9-105(1)(b) requires that the paper evidence "both a monetary obligation and a security imterest

111. The term chattel paper applies when a lessor transfers his interest in the paper to another; however, there is nothing in the definition of chattel paper in section 9-105(1)(b), or elsewhere in the Code, to preclude use of the term to describe the transfer by the lessee of its interests under the lease. Alternatively, the lessee can be viewed as transferring a general intangible (the use, possession, and enjoyment of goods) or an interest in goods (the leased goods). See Vagts, The Uniform Commercial Code and the Oil and Gas Mortgage, in 43 Texas L. REv. 825, 840-41 (1965), reprinted in [1982] P. CoOgaN, W. Hogan \& D. VAGTS, 1B SEcured Transactions under U.C.C. (MB) $\$ 16.15[8]$ (mortgage on oil and gas leasehold is a general intangible under the UCC because there is no right to payment); Note, Mineral Leases are Excluded from Coverage of the Uniform Commercial Code for Security Purposes, 23 U. KAN. L. REv. $367-76$ (1975) (review of cases holding that oil and gas leaseholds are personal property). It is doubtful, however, that the chattel paper rules were ever intended to apply to assignments of the lessee's leasehold; the essence of the chattel paper definition is the monetary obligation owed to the holder of the paper. See Kripke, Chattel Paper, supra note 5, at 1211-12.

112. See U.C.C. \$ 9-105 comment 4.

113. This category also includes paper that consists of a security agreement and a note that fails to comply with the tecfinical requirements of negotiability under U.C.C. \& 3-104(1).

114. This type of chattel paper could thcoretically be composed of a lease and negotiable notes, but as a practical matter the lease includes the promise of payment.

Many commentators completely overlook the fact that the definition of chattel paper can include leases and proceed as if chattel paper always includes a security agreement. Perhaps these writers interpret the reference to leases in section 9-105 to mean bailment leases, the prototype of a disguised conditional sale; the Code, however, imposes no such limitation. See, e.g., Clark, Ab. stract Rights, supra note 107, at 447 (equating chattel paper with an abstract right in specific tangible property); Freedheim \& Goldston, Article 9 and Security Interests in Accounts, Contract Rights and Chattel Paper, 14 OHo ST. L.J. 69, 88 (1953) (section 9-105(1)(b) includes "chattel mortgages, conditional sales agreements, bailment lcases and any othcr writings which (a) create liens on personal property and (b) are ordinarily transferred by indorsement and delivery"); Weingarten, Article 9 of the U.C.C.: Definitions and Rules of General Application, 9 WAYNE L. REv. 537, 542 (1963). 
in or a lease of specific goods."11s Read literally, section 9-105(1)(b) excludes true leases from the definition of chattel paper in two ways. First, the requirement that chattel paper evidence a monetary obligation and a lease implies that the two are distinct and that the lease evidences a claim to goods on the part of the lessor's assignee. This is the case if the "lease" is a disguised security agreement, but not if it is a true lease. ${ }^{116}$ Second, the definition of chattel paper requires a lease of "goods," but the term "goods" is defined as "all things which are movable at the time the security imterest attaches . . ." 117 If the lease is a security lease, there is no problem. If the lease is a true lease, however, there is no security interest to attach to the leased items; therefore the leased items do not fit the definition of goods, and consequently the lease cannot be chattel paper.

Although the drafters' preoccupation with security leases explains the inention of leases in the chattel paper definition, it is unlikely that the drafters intentionally drafted the definition of goods to exclude true leases froin chattel paper. ${ }^{118}$ To avoid excluding true leases, the definition of goods should be read liberally ${ }^{119}$ to mean that items leased are goods if they are movable at the time the security interest attaches or at the time the lease is executed, ${ }^{120}$ and the definition of chattel paper

115. U.C.C. $\$ 9-105(1)(b)$. Early drafts of the chattel paper definition referred to a monetary obligation. See U.C.C. \& 8-106(4) (October 1949 Draft); U.C.C. \& 7-104 (May 1949 Draft). The reference was eliminated without explanation in the 1950 Proposed Draft and did not reappear until the 1956 Recommendations, again without explanation. Professor Kripke asserted that the requirement of a monetary obligation is more fundamental than the fact that an interest in chattels is taken of retained as security. Kripke, Chattel Paper, supra note 5, at 1211-12.

116. Although there was some indication under non-Code law that a lease evidences something more than the right to rentals, see supra notes $43-47$ and accompanying text, it seems clear that ownership rights, including contingent future interests, are not transferred by a lease, see supra notes 38.42 and accompanying text.

117. U.C.C. § 9-105(1)(h).

118. In the comments the drafters express the view that the clrattel paper definition encompasses true leases. See id. \& 9-105 comment 4.

119. See id. \& 1-102(1) (rule of liberal construction). Furthermore, the introductory sentence of section 9-105(1) states that its definitions apply "unless the context otherwise requires." Finally, section 9-105(1)(h) provides that the term " 'goods' includes all things which are movable. . . ." (emphasis added). The word "includes" suggests that this is merely an illustrative and not an exhaustive description of items classifiable as goods.

120. The attachment of a security interest and the execution of a lease are not, lowever, strictly analogous. In addition to a written agreenent, attachment requires that value be given and that the debtor have rights in the collateral, see id. $\S 9-203(1)$, whereas the execution of a lease requires neither of these. It is difficult to imagine where this discrepancy would have any practical impact; nevertheless, as an alternative, section 9-106(7) could be redrafted or interpreted to mean that items leased are goods if they are movable "at the time of the commencement of the lease term." 
ought not be read to imply a distinction between a monetary obligation and a lease. ${ }^{121}$

2. Transfer by Physical Possession of the Document. The specialty status of negotiables is founded on the fundamental propositions that certain rights or interests are embodied in the writing itself, that transfer of the writmg operates to transfer those interests, and that the individual in possession of the document can claim rights to the interests embodied in the writing. ${ }^{122}$ True leases do not possess these qualities; leases have never historically been treated as indispensable instruments such that transfer of the lease document would transfer the rights embodied in the document. ${ }^{123}$

The Code does not specifically provide that the transfer of chattel paper transfers the obligations it represents; nor does it specifically provide that perfection of a security interest in the written paper, for example, by possession, perfects a security interest in those obligations. ${ }^{124}$ It merely provides im section $9-305^{125}$ that "[a] security interest in ... chattel paper may be perfected by the secured party's taking possession of the collateral."126 Taking possession of the collateral, the chattel paper itself, would be meaningless unless the paper represented the underlying rights which are transferred by a transfer of the paper. Therefore, the necessary implication of section $9-305$ is that delivery of

121. It should be noted that if all leases were deemed to create security interests in the first instance, see Coogan \& Boss, supra note 7, $\$$ 4.3.01-4.3.05, this section would present no problems.

122. See U.C.C. $\$ 3-201,-302,-305(1),-305(2)$. Under the doctrine of merger, the document itself constitutes the obligation rather than merely being evidence of the obligation. Gilmore, Formalism and the Law of Negotiable Instruments, 13 CREIGHTON L. Rev. 441,449 (1979). The obligation therefore passes by delivery of the document, and is called a specialty. Kripke, Chattel Paper, supra note 5, at 1211.

123. See supra notes 53-68 and accompanying text.

124. If the written paper is equivalent to the obligation it represents, perfection of a security interest in the paper is the same as perfection of a security interest in the obligation. For example, section 9-304(2) specifically provides that a security interest in claims represented by a document (i.e., the goods covered by the document) is perfected by perfecting a security interest in the document. No such comparable provision exists with respect to chattel paper. See also U.C.C. § 3301.

Just as some commentators have questioned the importance of negotiability as an attribute of commercial paper, see supra note 107, others have questioned the desirability of possession as a means of perfection. See Coogan, Article Q -An Agenda for the Next Decade, 87 YALE L.J. 1012 (1978); Phillips, Flawed Peffection: From Possession to Filing Under Article \& - Part II, 59 B.U. L. REv. 209 (1979). These questions are especially pertinent when lease chattel paper is concerned, because inere possession of lease chattel paper was historically incousequential.

125. Section 9-305 groups chattel paper together with the other negotiable intangibles (instruments and negotiable documents). In contrast, a security interest in accounts or in general intangibles may not be perfected by possession because they are types of property "not ordinarily represented by any writing whose delivery operates to transfer the claim." U.C.C. \& 9-305 comment 1.

126. Id. \& 9-305. 
chattel paper operates to transfer the claim that the paper represents. ${ }^{127}$ This conclusion is supported by the case law, ${ }^{128}$ by the comments ${ }^{129}$ to the Code, and by its history. ${ }^{130}$ The apparent reason why the Code does not specifically provide that chattel paper is a symbolic document

127. Clark, Abstract Rights, supra note 107, at 464. Although a security interest in chattel paper may be perfected by possession, U.C.C. $\$ 9-305$, it also may be perfected by filing. Consequently, transfer of possession is not the only way to transfer the rights evidenced by chattel paper.

128. See American State Bank v. Avco Fin. Servs. of United States, 71 Cal. App. 3d 774, 139 Cal. Rptr. 658 (1977) (rights in chattel paper confer the right to dispose of the obligation that the paper represents); Bolduan v. Normandin (In re Western Leasing, Inc.), 17 U.C.C. Rep. Serv. (Callaghan) 1369 (Bankr. D. Or. 1975) (sale of chattel paper covering motor vehicle perfected by possession of chattel paper, and title certificate registration not required to perfect rights in the contract). These cases are consistent with non-Code cases where the transfer of a chattel inortgage or conditional sales contract was deemed to transfer the inonetary obligation and security evidenced by the contract. See supra note 69 (cases cited).

129. See U.C.C. \$ 9-105 comment 3 (in the case of instruments and chattel paper, "delivery" of the writing is the minimum required to transfer the interest represented therein); id. \$ 9-106 comment (contrasting negotiable or quasi-negotiable commercial paper such as chattel paper with accounts that "are not evidenced by an indispensable writing"); id. \$ 9-305 comment 1 (contrasting chattel paper with accounts and general intangibles, which are "not ordinarily represented by any writing whose dehvery operates to transfer the claim").

The comments to the 1962 text of section 9-103 are the most specific:

[I]n contemplation of law and by common understanding and practice the property right or claim evidenced by an instruinent, document or chattel paper is thought of as being merged in or symbolically represented by the piece of paper, whose endorsement or de-

livery is a prerequisite to a transfer of the underlying claim or rights.

U.C.C. \$ 9-103 comment 2 (1962).

130. Earher versions of the Code included a delivery test in the definition of chattel paper. See U.C.C. \& 9-105(1)(b) (1952) (chattel paper is "a security agreement or a lease of a type which is in ordinary course of business transferred by delivery with appropriate indorsement or assignment"); id. \$ 9-105 comment 1; U.C.C. \& 8-106(4) comment 4 (1949 Draft) (chattel paper contains an obligation which is "customarily transferred by a transfer of the writing"); $i d$ comment 3.

This definition of chattel paper quickly came under attack for its ambiguity. See, e.g., Memorantion of Task Group 4, reprinted in [1954] 2 N.Y. L. REVISION COMM'N REPORT 1020; Memoranchom of Information to be Obtained at Public Hearing, reprinted in [1954] 2 N.Y. L. REVISION COMM'N REPORT 1082. Supporters of the definition pointed to conditional sales contracts and chattel mortgages as examples of chattel paper. See, e.g., [1954] 2 N.Y. L. REVISION COMM'N REPORT 1088 (remarks of Prof. Charles Bunn). As one of its critics noted, however, "under present practice banks . . . do not require dehvery of non-negotiable paper such as conditional sales agreements." Id. at 1095 (remarks of Harold M. Sherman, Jr.). That critic and others pointed out that the delivery requireinent was commercially impracticable becanse retailers must retain possession of the written agreements in order to make exchanges and "add-ons," and to release paid contracts. See id at 1095-96 (reinarks of Harold M. Sherman, Jr.); id at 1125 (reinarks of Louis A. Russo, Vice President and counsel of Chase Manhattan Bank). Finally, the sheer imprecision of the test would leave banks to act at their peril. See id at 1282 (reinarks of Leonard W. Burdick, Esq.); see also id. at 1326 (remarks of G. Russell Clark of the New York Clearinghouse) (definition would "exclude the ordinary conditional sales contract and therefore complicates the use of conditional sales contracts as security").

In response to these criticisms, the 1954 amendments and the 1956 recommendations to the Code redefined chattel paper "to delete the uncertain test of delivery in ordinary course of business," U.C.C. \& 9-105(1)(b) comment (Recommendations 1956); see U.C.C. \& 9-105 Reasons (Changes \& Additions 1954). To conclude that these deletions demonstrate that a security interest in chattel paper can be perfected by possession even though the writing is not "one regarded as 
is that under non-Code law, security chattel paper, the focus of the drafters' attention, was already treated as representing the obligations it contained. Indeed, the Code's principal drafter maintained that to qualify as chattel paper under the definitional section 9-105(1)(b), the paper must be "transferable by delivery in the ordinary course of busmess."131

If the implied delivery requirement were essential to the definition of chattel paper, true leases would not qualify as chattel paper. True leases, however, meet the literal requirements of section 9-105(1)(b), and, contrary to Professor Gilmore's view, are chattel paper. ${ }^{132}$ As such, section 9-305 bestows on leases an important element of negotiability: a lease is treated as the embodiment of the rights it represents such that these rights are transferred by a transfer of the lease document. Although under this interpretation the Code confers on leases a characteristic totally alien to non-Code law, it may be justified on the grounds of unitary treatment for all leases. This result need not frustrate the expectations of the parties, because they may still transfer the lease without delivery of the lease document. ${ }^{133}$

3. Claims and Defenses of the Obligor. Another characteristic of negotiable paper is that the transferee takes free of the obligor's claims and defenses. ${ }^{134}$ Of all the attributes of negotiability, this is the one least characteristic of lease chattel paper. Section 9-318(1) states the basic principle that the rights of an assignee against an account debtor ${ }^{135}$ are subject to most claims of recoupinent and setoff, ${ }^{136}$ which

4ransferrable in the ordinary course of business" "is "nonsense." 1 G. GILMORE, SECURITY INTERESTS, supra note $1, \& 12.5$, at 379.

131. 1 G. GLLMORE, SECURITY INTERESTS, supra note 1, \& 12.5, at 379 (footnote omitted). "Despite the 1956 deletion, the 'uncertain test of delivery' must be reintroduced through the back door of necessary implication." Id. If the delivery test were reinstated, however, it would exclude true leases from the category of chattel paper. See supra notes 53-68 and accompanying text.

132. See U.C.C. \& 9-105 comment 4.

133. The perfection provisions under Article 9 , which contemplate permissive filing as to clattel paper, recognize that transfer of the rights can occur without physical transfer of the paper. See U.C.C. \& 9-305. Thus, although transfer by delivery is possible, it is not the exclusive means of assigning cliattel paper.

134. A holder in due course of a negotiable instrument under section 3-305 takes free of all "personal" defenses of the obligor, but takes subject to the "real" defenses listed in section 3305(2).

135. "Account debtor" means the person who is obligated on an account, chattel paper, or general intangible. U.C.C. \& 9-105(1)(a).

136. Under section 9-318(1), the rights of an assignee are subject to "(a) all the terms of the contract between the account debtor and assignor and any defense or claim arising therefrom; and (b) any other defense or claim of the account debtor against the assignor which accrues before the account debtor receives notification of the assigninent."

Section 9-308, which protects those in possession of chattel paper from most third party claimants, see infra notes 176-81 and accompanying text, does not preclude an account debtor 


\section{negates full negotiability for most assignments. ${ }^{137}$}

The general rule of section 9-318 is subject to an exception if "an account debtor has made an enforceable agreement not to assert defenses or claims arising out of a sale as provided in section 9-206."138 By its hteral language, however, the exception and its cross-reference to section' 9-206 apply to leases only if they are "sales," that is, sales disguised as leases.

The first sentence of section 9-206 partially remedies this apparent nonparallel treatment of lease chattel paper and security chattel paper. It permits "buyers or lessees"139 to make enforceable agreements not to assert defenses or claims against subsequent assignees. ${ }^{140}$ Section 9-206 applies whether the assignment by the account creditor involves security chattel paper, lease chattel paper, ${ }^{141}$ or simply an account. The first

from raising its defenses in a suit by a chattel paper possessor. First Nat'1 State Bank v. Reliance Elec. Co., 668 F.2d 725 (3d Cir. 1981); Chemical Bank v. Penny Plate, Inc., 144 N.J. Super. 390, 365 A.2d 945 (1976), affd, 75 N.J. 311, 381 A.2d 793 (1978).

137. To a great extent, section 9-318(1) simply codifies prior law. See RESTATEMENT OF SECURITY 8136 (1941); U.C.C. 8 9-318 comment 1 ; see also RESTATEMENT OF CONTRACTS $\$ \$ 168-$ 70 (1932). It applies not only to assignees of chattel paper, see Rehurek v. Chrysler Credit Corp., 262 So. 2 d 452 (Fla. Dist. Ct. App. 1972), but to assignees of accounts, see Ertel v. Radio Corp. of America, 261 Ind. 573, 307 N.E.2d 471 (1974); Fall River Trust Co. v. B. G. Browdy, Inc., 346 Mass. 614, 195 N.E.2d 63 (1964); Commercial Sav. Bank v. G \& J Wood Prods. Co., 46 Mich. App. 133, 207 N.W.2d 401 (1973), and to assignees of contract rights (where applicable), see First Fed. State Bank v. Town of Malvern, 270 N.W.2d 818 (lowa 1978); Massey-Ferguson Credit Corp. v. Brown, 173 Mont. 253, 567 P.2d 440 (1977).

138. U.C.C. 8 9-318(1) (emphasis added).

139. U.C.C. 8 9-206(1). Note that potential account debtors other than buyers or lessees are excluded from section 9-206. If, for example, an account creditor lends money to an account debtor and is granted a security interest in equipinent, section 9-206 would not render enforceable a provision in the security agreement that the account debtor will not assert any defenses against a subsequent assignee.

140. Prior courts were split as to whether such waiver agreements were enforceable; some courts held the provisions void as against public policy. See generally G. GILMORE, SECURITY INTERESTS, supra note 1, 8 41.5. By enabling a buyer or lessee to agrce to waive defenses, section 9-206 recognizes the general principle of freedom of contract embodied in the Code. See U.C.C. $81-102(3)$ and comment 2.

141. The 1957 Official Text of section 9-206 was limited to waiver agreements by "buyers." U.C.C. 89-206 (1957). The reference to lessees was added in the 1962 Official Text, and the comments to that text note that the "same rules are inade applicable to leases as to security agreements, whether or not the lease is intended as security." U.C.C. 8 9-206 comment 1 (1962). This revision required a corresponding change in the exception language of section 9-318(1), which the drafters of the Code apparently overlooked. For an interesting ease that applies Article 9 to true leases in a jurisdiction that has not adopted the 1962 amendments, see United Connties Trust Co. v. Mac Lum Inc., 643 F.2d 1140 (5th Cir. 1981).

It might seem that because Article 9 applies only to secured transactions, section 9-206 applies only if the transaction between the buyer or lessee and the seller or lessor is a secured transaction. This confuses the finance transaction with the underlying lease or sale. Although section 9-206 governs a waiver made in the lease or sale agreement, the section only applies when the rights under this agreement have been assigned and the assignee as a secured party attempts to 
sentence of section 9-206 does not confer specialty status on lease chattel paper because it does not automatically bar the account debtor's claims and defenses; it requires an explicit contractual waiver.

The second sentence of section 9-206(1) bestows specialty status on chattel paper, but only on security chattel paper. It provides that a buyer automatically waives its defenses and claims if "as part of one transaction [it] signs both a negotiable instrument and a security agreement . . ."142 This provision means in effect that when a negotiable instrument accompanies a security agreement, the negotiability of the former is imputed to the latter. ${ }^{143}$ If a lessee executes a true lease and a negotiable instrument, however, both of which are later assigned by the lessor to a secured party who then sues on the lease, the lessee inay raise defenses it had against the lessor. Section 9-206(1) will not protect the assignee of a true lease because of the absence of a "security agreeinent" and a "buyer."144

The literal language of sections $9-318$ and 9-206 is difficult to apply to lease chattel paper because it is limited to sales and to sales involving security agreements. Insofar as this is an oversight, and not a

enforce the waiver against the account debtor. See U.C.C. \&9-102(1)(a). Consequently, the courts have properly applied section 9-206(1) to validate and enforce waivers in true lease transactions. See United Counties Trust Co. v. Mac Lum, Inc., 643 F.2d 1140 (5th Cir. 1981) (section 9206(1) applies even though a sale-leaseback transaction is not a secured transaction); see also Walter E. Heller \& Co. v. Convalescent Home, 49 Ill. App. 3d 213, 365 N.E.2d 1285 (1977); Cliemical Bank v. Penny Plate, Inc., 144 N.J. Super. 390, 365 A.2d 945 (1976).

142. U.C.C. $\& 9-206(1)$.

143. Bautista \& Kennedy, supra note 5, at 601 (section 9-206 recognizes "limited roles" for imputed negotiability); see also Chicago City Bank \& Trust Co. v. Davidson, 42 Ill. App. 3d 386, 356 N.E.2d 128 (1976) (waiver of defense clause inparts some characteristics of negotiability). See supra notes 69-71.

144. U.C.C. \$ 9-206(1). If the lessee had executed an enforceable waiver of defense clause, however, the first sentence of section 9-206(1) would apply.

If the assignee of lease chattel paper who is also the holder of a negotiable instrument sues on the lease to recover the property, and the lessee attempts to assert its personal defenses, a court may follow one of three avenues:

(l) It may find that under the literal wording of section 9-206, negotiabihity is imputed to security agreements only, and hence a lessee's defenses are not cut of by its execution of a promissory note. See U.C.C. \& 9-318(1)(a), (b). Because the "imputed negotiability" principles of preCode law are displaced by sections $9-206$ and $9-318$, resort to that body of law under section l-103 would be inappropriate.

(2) It may find persuasive the drafters' official comment to the effect that the same rules apply to both true and security leases and impute negotiability to the lease either by direct application of section 9-206, see infra note 146, or by analogy.

(3) It may find that section 9-206 does not address the situation at all. Therefore, under section 1-103, the court may turn to pre-Code law to decide whether the lessee's defenses are cut off in such a situation.

In a suit on the note, however, the court would probably allow the assignee as the holder in due course of the note to sue on the note free of any personal defenses. See U.C.C. $8 \& 3-305,9-$ 308. 
deliberate choice on the part of the drafters to distinguish lease chattel paper and security chattel paper and to protect only holders of the latter, ${ }^{145}$ the unintended exclusionary consequences of the literal language nay be remedied by a hberal interpretation of the Code ${ }^{146}$ or by an amendment. In either event, unitary treatment could be accorded without any significant alteration in the expectations of the parties.

4. Repossessed and Returned Goods. The language of section'9$306(5)(b)^{147}$ on repossessed and returned goods also disrupts the unitary treatment of lease chattel paper and security chattel paper. The section refers only to chattel paper resulting froin the sale of goods, or to accounts arising froin the sale of goods, as opposed to chattel paper or accounts arising from the lease of goods. 148 If the sold goods are repossessed or returned, section 9-306(5)(b) provides that an unpaid transferee of the chattel paper (a security chattel paper financer) has a security interest in the goods against the transferor. ${ }^{149}$ When goods that have been leased rather than sold are repossessed or returned, however, the language of section 9-306(5) gives the lease chattel paper

145. The failure of section 9-318 to mention lessees is undoubtedly an oversight. One could argue, however, that the failure of section 9-206 to mention leases in the second sentence refiects the fact that with security chattel paper, the "lease" is secirity for the note, whereas with lease chattel paper the note is security for the lease. While theoretically this may be true, it does not justify non-unitary treatment. In many cases, a financer does not know whether the "lease" is a true lease or a security lease, and hence it is impossible to determine whether the "lease" was intended as security or as the primary obligation. One thing is clear: the lessee executed a note, which means that the parties knew that the lessee's claims and defenses would be cut off in a suit on the note. Given the need for unitary treatment of lease and security chattel paper, this waiver should also be effective in a suit on the lease; the theoretical considerations discussed above have no functional ramifications.

146. The section that defines "security agreement" gives a qualified definition which, applies "unless the context otherwise requires," see U.C.C. $89-105(1)$, and the section that defines "sale" is arguably similarly qualified. See id. \& 2-106(1) (which apphies to Article 9 under section 9105(2)). It is therefore possible that given the drafters' intent to accord unitary treatment to lease chattel paper and security chattel paper, the terms "sale" and "security agreement" in sections 9318 and $9-206$ are to be hberally interpreted to imclude lease transactions. See id. \& 1-102(1) (iiberal interpretation provision).

147. On the general apphication of section 9-306(5)(b) to returned or repossessed goods claimed by a chattel paper financer, see Levie, supra note 18, 828.04 [5] [b]-[d]; see also Skilton \& Dunham, Security Interests in Returned and Repossessed Goods Under Article 9 of the Uniform Commercial Code, 17 WILLAMETTE L.J. 779 (1981).

148. The section apphes only when "a sale of goods results in an account or chattel paper" and the goods are nltimately "returned to or are repossessed by the seller or the secured party." U.C.C. \$ 9-306(5) (emphasis added). But see Gutterman, supra note 80, at 357 (assuming without discussion that section 9-306(5) apphes to true leases).

149. The subsection provides:

(b) An unpaid transferee of the chattel paper has a security interest in the goods against the transferor. Such security interest is prior to a security interest asserted under paragraph (a) [by an inventory financer] to the extent that the transferee of the chattel paper was entitled to priority under Section 9-308.

U.C.C. $89-306(5)(b)$. 
financer no such security interest. 150

It is arguable that the restrictive coverage of section 9-306(5) merely recognizes the difference between a security chattel paper financer (who by virtue of the chattel paper has a security interest in the leased goods) and a lease chattel paper financer (who has no independent claim to the goods); ${ }^{151}$ in each case the section gives the financer no inore than that for which the financer bargained. This argument is undermined by section 9-306(5)(b), which provides that an unpaid transferee of an account also "has a security interest in" repossessed or returned goods. ${ }^{152}$ An accounts receivable financer is generally lending on the basis of unsecured obligations, and therefore any security interest it may have in the goods arises as a direct result of section 9-306(5). The transfer of a true lease is very similar to the transfer of an account; ; $^{153}$ this similarity and the parallel structure of subsections 9-306(5)(b) and 9-306(5)(c) suggest that it would be appropriate to allow a lease chattel paper financer to take a security interest in returned or repossessed goods under subsection 9-306(5)(b) even though it had no security interest in the leased goods before their return or repossession.

Thus, there is no reason why the scope of section 9-306(5)(b) should be limited to security chattel paper. Whether the chattel paper represents a true lease or a security lease, the chattel paper financer

150. If the lease chattel paper financer takes a security interest in the reversion, however, he will have a security interest in the goods even if the goods are returned or repossessed. Therefore, one solution is to provide that the transfer of a trie lease transfers the reversion, although this is contrary to non-Code law, see supra notes 38-42 and accompanying text. This approach is no less problematic, however. See infra notes 163-73 and accompanymg text.

15I. It is also arguable that section $9-306(5)(b)$ is merely part of a section that governs priorities and cannot operate to create a security interest where none previously existed. According to Professor Gilmore, the drafters of section 9-306(5) were principally "concerned with priorities between an imventory financer and a purchaser of receivables." 2 G. GILMORE, SECURITY INTERESTS, supra note $1, \S 27.5$, at 737. Consequently, section 9-306(5) was restricted to situations where there has been a sale of goods and subsequent transfer of the resulting account or chattel paper. Yet Professor Gilmore would apply the section even where there has been no credit sale or transfer of an account or of chattel paper. Id. at 736. The history of section 9-306(5) also recognizes that the subsection may be applied by analogy to situations outside its technical reach. See U.C.C. \$ 9-306(5) comment 4 (I952); see also 2 G. GILMORE, SECuRITY InTERESTS, supra note I, $\$ 27.5$.

Furthernore, although the introductory language to section 9-306(5) states that "the following rules determine priorities," the section also gives security interests to accounts receivable financers who did not possess them as the result of an agreenent. Thus, section 9-306(5) is not a mere priority section. See infra note 152 and accompanying text. Moreover, although the May 1949 Draft required an express agreement granting the chattel paper financer a security interest in returned or repossessed goods before the financer could claim them, U.C.C. \& 7-318(2) (Tent. Draft 1949), the requirement was eliminated from later drafts.

152. U.C.C. $\$ 9-306(5)(c)$ and $\$ 9-306$ comment 4.

153. See supra notes $100-06$ and accoinpanying text. 
bases its loan on paper evidencing a certain monetary obligation. The lessor reduces the lessee's obligation under the lease, and thwarts the financer's rights to payment by accepting the return or repossession of the goods and terminating the contract. Even if the lessee's obligation to pay is not terminated, the financer's ability to enforce that obligation is jeopardized. It seems appropriate, therefore, to give the financer some ability to recoup by allowing it to have recourse against the debtor-lessor and against the returned goods in particular.

The fact that a lease chattel paper financer may have recourse to the returned or repossessed goods under section 9-306(2) as "proceeds" of the chattel paper ${ }^{154}$ does not justify the exclusion of lease chattel paper from the provisions of section 9-306(5)(b). ${ }^{\text {iss }}$ If the claim of the lease chattel paper financer to returned or repossessed goods were governed by subsection 9-306(2) (proceeds) and the security chattel paper financer's claim were subject to subsection 9-306(5)(b) (returned or repossessed goods), courts would be forced to distinguish between the two types of chattel paper in order to determine which section to apply. This would create unnecessary confusion. Furthermore, because section 9-306(5)(b) may protect the financer in a larger number of settings, ${ }^{156}$ the security chattel paper financer would receive better protection than the lease chattel paper financer. Second, to obtaim protection under section 9-306(5)(d) from creditors of, or purchasers from, the account creditor, a security cliattel paper financer must perfect as to the returned goods ${ }^{157}$ by taking possession of thein or by filing a financ-

154. See 2 G. GILMORE, SECURITY INTERESTS, supra note 1, $\$ 27.5$, at 737 ("it does not seem overfanciful to call [returned or sepossessed] goods 'proceeds' "). But see infra note 171 and authorities therein cited (proceeds do not result from a lease of goods).

155. Alternatively, the financer may rely on section 9-318(2), which provides that if an unearned right to payment is assigned, the assignee has corresponding rights under any modified or substituted contract.

The prudent financer of lease chattel paper will include a specific provision in the lease financing agreement granting it a security imterest in any returned or repossessed items. Furthermore, if the lessor/assignor has inventory financing as well, the financer of the lease chattel paper should demand an interlender agreennent which recognizes the priority of its interest in the leases and in any returned and repossessed goods. See Gutterman, supra note 80, at 357.

156. In most cases, sections 9-306(5)(b) and 9-306(2) and (3) render similar results. But when the return occurs without the consent of the chattel paper financer and the debt is not extinguished (for example, if the lessee has executed an enforceable nonwaiver agreement), the returned goods are not "received upon the ... exchange ... or other disposition" of the debt, see U.C.C. \$9-306(1), and section 9-306(2) is inapplicable. See Skilton \& Dunham, supra note 147, at 804. Moreover, subsections 9-306(1), (2), and (3) would not apply to the interest of a chattel paper financer in goods that are repossessed on the account debtor's default. Id. at 805 . In these cases, a lease chattel paper financer forced to rely on section 9-306(2) would go unprotected while a security chattel paper financer in similar circumstances could rely on section 9-306(5)(b).

157. U.C.C. \$9-306(5)(d). See also id. § 9-306 comment 4. 
ing statement that describes the goods or identifies thein by type. ${ }^{158} \mathrm{~A}$ lease chattel paper financer, who may claim the goods as proceeds under section 9-306(2), has the benefit of simpler perfection procedures. ${ }^{159}$ ?

There has been some suggestion that section 9-306(5) is mere surplusage in the Code. ${ }^{160}$ If one accepts both its existence and the desirability of unitary treatment of security and lease chattel paper, however, section 9-306(5) should be read liberally or amended to cover the return or repossession of leased goods. ${ }^{161}$ There is no reason why security chattel paper financers should be able to recoup their losses but lease chattel paper financers should not. ${ }^{162}$

\section{Major Bifurcations of the Unitary Scheme.}

In contrast to the minor bifurcations ${ }^{163}$ of the unitary treatmeut of lease chattel paper and security chattel paper under Article 9, other

I58. See 2 G. GLLMORE, SECURITY INTERESTS, supra note 1, 8 27.5, at 737-38; Skilton \& Dunham, sipra note 147, at 819-36; see also In re Haugabook Auto Co., 9 U.C.C. Rep. Serv. (Calla'ghan) 954 (Bankr. M.D. Ga. 1971); Osborn v. First Nat'l Bank, 472 P.2d 440 (Okla. 1970).

159. Under the 1962 Code, a security interest in proceeds is perfected if there is a filing statement covering the chattel paper and proceeds. U.C.C. \& 9-306(3)(a) (1962) (amended 1972). Under the 1972 Code; the financing statement need not even claim proceeds for a security interest to be perfected in them. U.C.C. 8 9-306(3)(a) (1972).

160. See Skilton \& Dunham, supra note 147, at 857 (concluding they would "probably like to put an end" to section 9-306(5)).

16I. It is arguable that the resulting security micrest would be an interest in the lessor's reversion, which seems contrary to the-non-Code principle that transfer of a lease never transfers the lessor's reversion, see supre notes $38-41$ and accompanying text. If, however, the lease chattel paper financer's security interest in the returned or repossessed goods is limited to the value of the balance of the lease tern after the goods are returned or repossessed, there would be no grant of an intereat in the reversion. See Coogan \& Boss, supra note 7 (suggesting amendments to Article 9 which would limit the lessee's credit to that amount fairly attributable to the remaining lease term). If the financer's security interest were not so limited, an interest in the reversion would be created. The Code gives little guidance on this issue, which demonstrates the difficulty of applying the remedies provisions of Article 9 to true leases. See DeKoven, supra nole 10, Proceedings after Defoult by the Lissee Under a True Lease of Equipment \& 29B.05. While the problem is less likely to arise in a security chattel paper context because the amounts of the payments often approximate the value of the goods, it still-may arise. See Skilton \& Dunham, supro note 147, at 792.93.

162. If the essignment of the chattel papor is without recourse and the return of the goods is rightful and extinguishes the underlying debt (for example, if the lessee signed no enforceable waiver of defense clause), the financer has no claim to the returned goods as proceeds under section 9-302(5); it has assumed the risk of a loss in this financing situation. Consequently, giving the financer security interest in the returned goods under section 9-306(5) gives the financer more than that for which it bargained. Arguably, this is the result whether the lease is a true lease or a security lease. However, to the extent that section 9-306(5) is viewed as reallocating the risk following a return or repossession of the goods, there is no resson to give the benefit of this reallocation to a socurity chattel paper financer but not to a lesse chattel paper financer.

$\therefore$ 163. See supra text accompanying notes 111-62. 
disruptions in the unitary scheme rightly reflect the inherent distinction between true leases and security agreements. In such instances, the difficulty of distinguishing between true leases and disguised conditional sales may not justify defeating the parties' intent to transfer a lease, rather than an interest in the leased chattel. These major bifurcations spring froun two non-Code principles: that a true lease document is not the indispensable embodiment of the right to rentals such that transfer of the lease document is necessary to transfer the right to rentals; ${ }^{164}$ and that a true lease represents primarily the right to rentals and their ancillary covenants ${ }^{165}$ and not the lessor's reversionary interest in the leased goods. ${ }^{166}$ The major bifurcations could be avoided and unitary treatment achieved by a departure from these principles, but the confusion and frustrated expectations that would result would outweigh the benefit of obviating the distinction between true leases and security leases.

If it were true that a lease document, like a disguised conditional sales agreement or a security agreement, embodied the rights it represents, and that those rights included the right to the lessor's reversionary interest in the goods, these deviations from non-Code principles would enable coinplete unitary treatment of leases and security agreements at the finance level. Under this scheme, however, the lease chattel paper financer who is the transferee of the lessor's rights under the lease would rcceive not only the right to rentals but the reversionary interest as well. This might give the financer more than that for which it bargained. ${ }^{167}$ Because both the right to rentals, including any ancillary covenants, and the right to the reversion would be forinalized in one lease document, with claims to either of these rights contingent on possession of that same document, it would be impossible to create a

164. See supra notes $64-68$ and accompanying text. This article has argued that it is necessary for the sake of unitary treatment to permit the transfer of a lease by delivery of the lease document. See supra notes 122-33 and accompanying text. It is nevertheless still possible to transfer the lease without delivery of the document. See supra note 133.

165. See supra notes $43-45$ and accompanying text.

166. See supra notes $40-42$ and accompanying text.

167. Assume that a manufacturer of machinery enters into a true lease for a period shorter than the life of the machinery. The machinery is worth $\$ 50,000$, the rentals amount to $\$ 15,000$. Suppose the written lease, not simply the lease payment rights, is assigned, along with other paper, to a financer in return for a loan of $\$ 25,000$ to a manufacturer. The manufacturer defaults im payments on the loan. If the transfer of the lease operates at law to pass the reversion, the financer now has a security imterest in the $\$ 15,000$ stream of rental paynents and the $\$ 50,000$ piece of equipment. Under non-Code law, the financer would have only a security interest in the rentals unless there were an express, separate security agreenent giving him a security interest in the reversion. In essence, the financer is being given an additional $\$ 50,000$ in security, considerably more than that for which it bargaimed, and more than it would have had under non-Code law. 
possessory security interest in either right individually. ${ }^{168}$ Thus, a prior holder of an interest in the reversion might have its interest defeated by a subsequent chattel paper financer. 169

Furthermore, a transferee of the reversion who was purchasing equipinent subject to a short-term lease might find itself in a peculiar situation as a result of the unitary scheme. Because the reversion would be an interest evidenced by chattel paper, the transfer of the reversion would be a sale of chattel paper and would fall under the coverage of Article 9,170 and an outright purchaser of equipinent would be transformed into a secured creditor. To protect its purchase properly, the purchaser would have to take possession of the short-term lease document. This would be a radical change in the expectations of parties to a sale of goods: Article 9 is not intended to apply to an outright sale, and an outright purchaser ought not be required to take possession of extraneous paper.

The situation would become even inore complicated if a inanufacturer gave a financer a security interest in equipment which at the time was not subject to any lease. If the equipinent were later leased and chattel paper generated, the financer's security interest in the equipinent would becoine a claimed security interest in the chattel paper as proceeds, ${ }^{171}$ and the financer would run the risk that a subsequent purchaser of the paper, who took possession of it, might gain priority over it. ${ }^{172}$

These problematic consequences of a truly unitary scheine ${ }^{173}$ not only abrogate the non-Code characterization of a true lease, they also

168. Furthermore, if a lessor is in possession of chattel paper encompassing several.rights, only one of which is transferred to a financer, the lessor would understandably be reluctant to transfer possession of the written document, because doing so could be construed as an imtent on his part to create a security interest in the other rights evidenced in the lease.

169. U.C.C. \$ 9-308; see infra notes 170-72 and accompanying text.

170. See U.C.C. \$ 9-105 comment 4; infra notes 189-192 and accompanying text.

171. One Code case, In re Cleary Bros. Constr. Co., 30 U.C.C. Rep. Serv. (Callaghan) 1444 (Bankr. S.D. Fla. 1980), holds that rentals earned are not proceeds of the leased collateral. This holding wonld be impossible if the Code provided that when an interest is evidenced by chattel paper, a claim to that interest is made by claiming the chattel paper. Once the chattel paper was generated, any claim directly to the property would be replaced by a claim to the chattel paper, which includes the right to rentals.

It could be argued that the equipment financer still has a claim to the equipment directly, so that the claim to chattel paper is irrelevant. The equipment claim will be cut off by section 9 $306(2)$, however, if the disposition was authorized. Furthermore, if the equipment is returned or repossessed, and if section 9-306(5) applies, see supra notes 147-62 and accompanying text, the equipment financer may be subordinated to the chattel paper purchaser under section 9-306(5)(b). The essence of the paperization primciple is that the holder of the paper prevails against holders of the abstract rights represented by the paper. See Clark, Abstract Rights, supra note 107, at 473-77.

172. See U.C.C. \& 9-308(b).

173. See infra notes $186,191-92$ and accompanying text. 
defeat the expectations of the parties to a true lease financing transaction and bring within the coverage of Article 9 the transfer of the lessor's reversionary interest, which, if it is an outright sale, should not be governed by Article 9 . The unitary scheine effectively turns true leases into security agreements even though the parties intended only the assignment of a lease. This cannot be justified without a complete examination of the impact of unitary treatment on lease mventory financing to determine whether the benefits of unitary treatment outweigh the impact of upheaval in established cominercial transactions. It appears better to grapple at the finance level with the distinction between true leases and disguised conditional sales than to thwart so completely the parties' expectations. Therefore, the major bifurcations of the unitary scheme described below ought not be remedied, despite the Code's professed commitment to unitary treatment of true leases and security agreements on the finance level.

1. A true lease is not an indispensable instrument. Under nonCode law, a true lease document does not embody the rights that it represents. ${ }^{174}$ The Code changes non-Code law to the extent that a claim to the chattel paper is in effect a claim to the rentals. The Code does not, however, specifically provide that a claim to the rentals inay be made only by claiming the chattel paper. Security chattel paper, though, has that characteristic of imdispensability. The difference between true leases and security leases results im a major bifurcation in the Code's unitary treatinent of the degree of negotiability accorded.

An important attribute of negotiability is that it enables a transferee of the writing to defeat the claims of third parties. ${ }^{175}$ Although the Code does not address the problem of imputed negotiability, ${ }^{176}$ it does provide that under certam conditions the purchaser ${ }^{177}$ of chattel

174. See supra notes $64-68$ and accompanying text and note 32 .

175. See U.C.C. $\$ \$ 3-305(1),-502$. Section 7-503 lists exceptions to the rule involving claimed interests in goods which existed prior to the issuance of the negotiable document. See Dolan, Good Faith Purchase and Warehouse Receipts: Thoughts on the Interplay of Articles 2, 7, and 9 of the U.C.C., 30 HASTINGS L.J. 1 (1978).

176. Prior to the advent of the Code, it was disputed whether the doctrine of imputed negotiability insulated the holder in due course of a note from claims of third parties to the collateral securing the note. See, e.g., Peninsula Bank v. Wolcott, 232 F. 68 (4th Cir. 1916); Myers v. Hazzard, 50 F. 155 (C.C.D. Neb. 1881); Grower's Fin. Corp. v. Hildreth, 30 Ariz. 505, 249 P. 71 (1926); First Nat'1 Bank v. Brotherton, 78 Ohio St. 162, 84 N.E. 794 (1908); W. W. Kimball Co. v. Mellon, 80 Wis. 133, 48 N.W. 1100 (1891). It can be argued that the Code rejects the doctrine of imputed negotiability. See Bautista \& Kennedy, supra note 5, at 600-02.

177. The definition of "purchaser" in U.C.C. \& 1-201(32) includes one who takes a security interest. See In re Samuels, 510 F.2d 139, 154-60 (5th Cir. 1975) (Godbold, J., dissenting), adopted en banc, 526 F.2d 1238 (5th Cir.), cert. denied, 429 U.S. 834 (1976); United States v. Wyoming Nat'l Bank, 505 F.2d 1064 (10th Cir. 1974); In re Bowman, 25 U.C.C. Rep. Serv. (Callaghan) 738 (Bankr. N.D. Ga. 1978). But see In ie American Food Purveyors, Inc., 17 U.C.C. Rep. Serv. 
paper takes free of the claims of third parties under section 9-308. ${ }^{178}$ Even the interests of a prior outright purchaser may be subordinated to those of a secured party in possession, though, since the interest of a buyer of chattel paper is a security interest, ${ }^{179}$ and section $9-308$ also provides that a security interest may lose priority to the possessory security interest of a subsequent secured party. ${ }^{180}$ Under section 9-308, then, chattel paper is treated as a quasi-negotiable specialty. ${ }^{181}$

The application of section 9-308(a) to lease chattel paper may have different consequences depending on whether the chattel paper is lease chattel paper or security chattel paper. This bifurcation results in less

(Callaghan) 436 (Bankr. N.D. Ga: 1974) ("purchaser" does not include secured creditor for purposes of U.C.C. \& 2-702).

178. Section $9-308$ provides that:

A purchaser of chattel paper or an instrument who gives new value and takes possession of it in the ordinary course of his business has priority over a security interest in the chattel paper or insirument

(a) which is perfected under Section 9-304 (permissive filing and temporary perfection) or under Section 9-306 (perfection as to proceeds) if he acts without knowledge that the specific paper or instrument is subject to a security interest; or

(b) which is claimed merely as proceeds of inventory subject to a security interest (Section 9-306) even though he knows that the specific paper or instrument is subject to the security imterest.

179. U.C.C. $881-201(37), 9-102(1)(b)$.

180. A prior outright purchaser is considered a secured party subject to Article 9's perfection and priority provisions. See U.C.C. 88 1-201(37), 9-102(1)(b), 9-105(1)(c), (d), (m). It can be argued that once chattel paper has been sold, the seller no longer has any rights in the collateral which would preclude a subsequent grant to another under section 9-203(1)(c). The seller of chattel paper, however, is a debtor, and section 9-311 allows the rights of the debtor in collateral to be transferred despite the grant of the first security interest. The comment to section 9-311 declares as its purpose "[t]o make clear that in all security transactions under this Article, the debtor has an interest (whether legal title or an equity) which he can dispose of and which his creditors can reach."

The thrust of bringing all sales of chattel paper and accounts within Article 9 is to require the buyer to perfect its interest or run the risk of subordination to subsequent creditors, purchasers, or assignees. G. GILMORE, SECURTTY INTERESTS, supra note 1, \& 10.5. If section 9-203 were read literally to preclude the creditors or assignees of a seller of chattel paper from reaching that paper, even though the previous buyer may not have perfected, the underlying purpose of the Code would be defeated.

It can then be argued that if a chattel paper purchaser files, subsequent assignees or creditors may not reach the paper, even if the purchaser does not take possession. This argument ignores the clear wording of section 9-308 and selectively applies section 9-203(l)(c) to cases of perfection by filing (but not nonperfection or perfection by possession where section 9-308 controls).

181. The prevailing custom, in the business and financial communities, of treating such paper as a commercial specialty led to the adoption in section 9-308, with respect to the [third party's] nonpossessory interest, of a rule of priority [in favor of the purchaser in possession] which might be described as one of quasi-negotiability.

2 G. GlLMORE, SeCuRITY INTEREsTs, supra note $1,825.5$, at 639 . See also supra note 107.

Chattel paper is not completely negotiable under the Code and is not given all the eleunents of indispensability. For example, possession is not the only way to perfect a security interest in chattel paper, perfection by filing is also permissible. U.C.C. $\$ 9-304(1)$ (security interest in chattel paper may be perfected by filing, but possession is necessary for money or instruments). 
protection for the lease chattel paper financer. ${ }^{182}$ Suppose a lessor of goods transfers the lease to financer $A$, who gives new value and takes possession of the lease docuinent in the ordinary course of business. Suppose, however, that the lessor had previously given a security interest in the rentals to soine third party $X$, as collateral for a loan, and that $X$ perfected its security interest by filing as to the rentals. If the lessor defaults, both $A$ and $X$ inay lay claim to the rentals. Under the first to file rule, $X$ would win; the question is whether section 9-308 alters this result.

Section 9-308 only applies to conflicting security interests in the chattel paper. It can be argued that $X$ 's claim to the rentals in effect is a claim to the lease chattel paper, ${ }^{183}$ and not a claim to the income

182. For example, section 9-308 protects a security chattel paper financer against any security interests in the note that are perfected under the temporary perfection provision in subsections 9 304(4) and (5), or which arise as claims to proceeds under section 9-306. These aspects of section 9-308 generally will not protect a lease chattel paper financer because subsections 9-304(4) and (5) apply only to security interests in instruments, negotiable documents, or goods in possession of a bailee. See U.C.C. $\$ 9-304(4),(5)$ and 9-304 comment 4. These aspects would protect a lease chattel paper financer only if the paper were to include a negotiable instrument. In such a ease, it would be the instrument and not the lease which would give the financer his preferred status. Claims to the chattel paper "as proceeds" under section 9-306 are similarly irrelevant if the chattel paper is a true lease: if a third party has a prior security interest in property which is then leased, the rentals arguably may not be proceeds because the collateral has not been sold, exchanged, collected or otherwise disposed of. Id. \$ 9-306(1). See In re Cleary Bros. Constr. Co., 9 Bankr. 40 (Bankr. S.D. Fla. 1980) (the words "otherwise disposed of" mean only a final disposition, not a temporary disposition of the collateral). CF. U.C.C. \$ 9-504(1) ("secured party after default inay sell, lease or otherwise dispose of" collateral) (emphasis added). But see Weiss, Original Collateral and Proceeds: A Code Puzzle, 42 N.Y.U. L. REv. 785 (1967), updated in [1982] P. CoogaN, W. Hogan \& D. VAGTS, IC SECURED TRANSACTIONS UNDER U.C.C. (MB) § 24.12[2] n.82 (criticizing Cleary because it requires a distinction between true leases and security agrecments). While the merit of this proceeds argument is doubtful, the fact remains that the prior secured party's security interest in the leased equipment inay continue despite the lease, and the equipment itself is the primary collateral for the secured party.

The result in Cleary accords with the general pre-Code rule that the mortgagee could not claim the earnings of mortgaged chattels during the time they were in the possession of the mortgagor and before his default unless the mortgage itself authorized the claim. $1 \mathrm{~L}$. JONES, supra note $10, \S 675$. Cleary apparently would not preclude a secured party with a security interest in the leased chattel froin making the right to collect rents a term of the security agreement. See Feldman v. National Bank of North America, 511 F.2d 465, 467 (2d Cir. 1975). In a sense, the fact that section 9-308 gives greater protection to security chattel paper finaneers than to lease chattel paper financers is another major bifurcation of the unitary scheme.

183. Under this approach, $X$ could not claim a security interest in the rents as such, but would have to claim a security interest in the lease chattel paper, which would bring it within the ainbit of section 9-308. A financing statement would have to describe the collateral as specific chattel paper or as rentals due under a specific lease, not as accounts receivable. Compare In re Upstate Tanks, Inc., 30 U.C.C. Rep. Serv. (Callaghan) 1700 (Bankr. W.D.N.Y. 1981) (description of accounts receivables does not sufficiently describe lease chattel paper) with EAC Credit Corp. v. King, 16 U.C.C. Rep. Serv. (Callaghan) 469 (5th Cir. 1975) ("accounts receivables" in guarantee includes chattel paper and leases). This filing, however, wonld be insufficient to protect $X$ 's interest against $A$ 's possessory security interest in the lease. $A$ 's interest would be protected by section 
stream per se, which would be an account. ${ }^{184}$ Financing policy would seem to dictate, however, that it be possible for a lessor to transfer the rentals alone, without the other benefits contained in a lease; if a claim to rentals inust be made through a claim to chattel paper, the accounts receivable finaricing of many lessors inay be affected. On the other hand, if a claim to rentals may be made independently of the claim to the lease, financer $A$ in the above example, as a transferee in possession of chattel paper, would not be protected against $X$ 's claim under section 9-308 which protects $A$ only agamst a conflicting security interest in the paper itself. Hence the priority battle between $A$ and $X$ will probably be resolved in favor of $X$ under the general principles of section 9-312.185

Therefore, while section 9-308 gives absolute protection to financers in possession of security chattel paper, financers who take possession of lease chattel paper nay nevertheless have their claims defeated by competing claims to the rentals theinselves. Again, this inajor bifurcation could be remedied ouly if a claim to the lease docuinent were necessary to claim the rights it represents. Under this principle, $X$ in the example above could have no security interest in the rentals without a security interest in the lease document, and therefore possession of the document by $A$ would fully protect its claim. This interpretation of the Code should not be adopted without a thorough analysis of the impact of this rule on accounts receivable and inventory financing. ${ }^{186}$

9-308. Yet, as Professor Clark observed, where the general purpose definition is being used to determine an important conceptual problen it "may be wondered whether the UCC draftsmen gave much explicit thought to the precise priority problem under discussion." Clark, Abstract Rights, supra note 107, at 452. Many authorities have assumed that a lessor may create a security interest in accounts, that is, in rentals, rather than in the lease. See Levie, supra note $18,8828.02$ .05; compare L. Dennon, Secured Transactions Under the Orioinal and the Revised U.C.C. (P.L.I. 6th ed. 1974) $\$ \$ 6.54-6.5404$ (no mention of the transfer of chattel paper in discussion of chattel lease financing) with id. 86.53 (assignment of chattel mortgage or conditional sale is accompanied by transfer of contract to financer).

184. An account is a right to payment of money "not evidenced by an instrument or chattel paper ..." U.C.C. \& 9-106. Presumably, if such a writing exists, the right to payment would cease to be an account. Hence it has been observed that under a blindly literal interpretation of section 9-106, an account and a note (or presumably an account and chattel paper) cannot exist simultaneously. Clark, Abstract Rights, supra note 107, at 452.

185. See U.C.C. \& 9-312(5)(a) (giving priority to security interests "according to priority in time of filing or perfection").

I86. Professor Clark has presented a forceful argument that the Code's paperization of abstract rights should not be interpreted as eliminating independent claims to the abstract right unless there is a strong sense of custounary practices and expectations which support that interpretation. See Clark, Abstract Rights, supra note 107, at 463 . In the absence of such practices, he favors allowing the recording rather than the possession to control, as he views the recording 
2. A true lease does not transfer the lessor's reversionary interest. Under non-Code law, a true lease represents the right to rentals. Transfer of the lease transfers this right, and perhaps also the right to benefit from any ancillary covenants in the lease. ${ }^{187}$ Transfer of the lease does not transfer the lessor's reversionary imterest in the goods at the end of the lease term: ${ }^{188}$ This principle causes two major bifurcations in the Code's unitary treatment of lease and security chattel paper, which arise because transfer of the latter transfers an interest in the secured goods as well as the right to payments.

(a) Article 9 does not cover a sale of the lessor's reversion. If security chattel paper is sold outright, Article 9 applies to the entire transaction, that is to the transfer of the right to money and to the transfer of the ownership interest in the chattel. By contrast, if lease chattel paper is sold along with the lessor's reversionary interest, Article 9 applies to the sale of the chattel paper, ${ }^{189}$ but not to the sale of the reversionary

principle as a more advanced rule, which "in a particular context of commercial practices and expectations will most efficiently reduce fraud costs and unfixity costs." Id. at 479.

187. See supra notes $43-47$ and accompanying text.

188. See supra notes $39-42$ and accompanying text, and text following note 44 .

189. Article 9 exphicitly applies to "any sale . . . of chattel paper," U.C.C. $₹ 9-102(1)(b)$, and hence to the assignment of the lease in question. Article 9, however, was intended to cover primarily security and other financing devices. See id. \& 9-102 Purposes, and comment 2; see also U.C.C. § 9-102(1)(b) (1952); 1 G. GILMORE, SECURITY INTERESTS, supra note 1, §10-5 at 309. The assignment of a lease in conjunction with the sale of the leased goods is neither a security arrangement nor a commercial financing arrangement, yet it does not fall within the exclusions listed in section 9-104(f). See U.C.C. \& 9-104(f). The sale of security chattel paper, on the other hand, will always be a financing transaction unless specifically excluded by section 9-104(f).

By not excluding transactions in which lease chattel paper is sold in conjunction with the sale of the reversion, the drafters achieved unitary treatment of lease chattel paper and security chatteI paper. This treatment was achieved at the expense of including within the scope of Article 9 transactions which are not financing transactions within the intended coverage of the Code. If the non-financing purchaser of lease chattel paper coupled with the lessor's reversion fails to take possession of the lease document, he risks losing his right to rentals under the lease if the lessor then fraudently sells the lease to a third party who takes possession of the lease document. See id. \$ 9-308; see generally supra notes $175-85$ and accompanying text. It is arguable that the Code should be liberally construed to protect thir purchase by excluding nonfinancing sales. See U.C.C. \& 1-102 (liberal construction rule); 1 G. GILMORE, supra note 1, \$10.5, at 309 (list of exclusions in section 9-104(f) is illustrative, not exhaustive). However, this would defeat the Code's policy of unitary treatment and commercial certainty and would open the door to litigation on whether the underlying lease is a true lease and whether the lease assignment is a financing transaction. Moreover, the exclusion of certain lease transfers froun Article 9 coverage would create priority problems between a party who claims a security interest in certain goods under Article 9 , and a purchaser of the goods in an excluded transaction: because Article 9 would not apply to the purchase, the purchaser would not be bound by the Article 9 rules on the creation and perfection of security interests. See Comment, UCC Section 9-30I(I) and Accounts, Contract Rights, and Chattel Paper: The Non-Existent Priorities?, 41 WASH. L. Rev. 895 (1966).

On the whole, excluding from Article 9 coverage sales of lease chattel paper that are coupled with a sale of the lessor's reversionary interest would do more harm than good. The inclusion of these transactions will probably cause only limited losses to innocent but ignorant purchasers who 
interest ${ }^{190}$ because under non-Code principles the transfer of a true lease does not transfer the lessor's reversionary interest. Consequently, a purchase of a "lessor's" right to rentals and rights in the leased equipment must be examined to determine whether the lease is a security lease, in which case Article 9 apphes to the entire transaction, or whether it is a true lease, in which case Article 9 applies only to the transfer of the rentals. Thus the scope of coverage under Article 9 depends in some cases on whether the paper assigned is lease chattel paper or security chattel paper.

This problem is not purely fornal; it has practical ramifications. Suppose a lessor, who is located in a state that has a certificate of title statute, has "leased" a car to a lessee, and the lessor's ownership interest in the car is appropriately noted on the certificate of title. The lessor then transfers all its rights in the chattel paper and the leased car to a purchaser. If the paper is security chattel paper, Article 9 controls the entire transaction, and if the purchaser takes possession of the chattel paper, that will perfect the purchaser's interest in the car. ${ }^{191}$ If the paper is lease chattel paper, on the other hand, Article 9 covers only the transfer of the rentals and not the transfer of the reversion. The certificate of title statute would apply to the transfer of the reversion-the lessor's ownership interest-and would require the purchaser to take further steps to protect its interest in the reversion. ${ }^{192}$

fail to take possession of the lease document. If the lease were for a short term, any purchaser of the goods and the lease, would be primarily interested in the goods, so his loss would be minimal if be lost priority rights to the rents under section 9-308. Moreover, the relatively short term of the lease would further decrease the possibility that someone would buy such paper in the ordinary course of business, as is required to achieve priority under section 9-308. If the lease were for a longer period of time more closely approximating the life of the leased goods, the purchaser undoubtedly would be primarily interested in the rentals. Although the possibility of a subsequent claim to the paper would be greater, the transaction would begin to look more like a financing transaction, and this type of purchaser would be more likely to protect himself by deunanding possession of the lease document. Although the present rule brings within the scope of Article 9 some transactions which are not of a financing nature, those situations (at least in the lease chattel paper area) are few. The defeat of legitimate expectations is minimal, and the umitary treatunent of all leases is highly beneficial.

190. Transfers of tangible personal property which are outright sales are not subject to Article 9, nor generally to any recording statutes. See U.C.C. \& 9-102. But see 49 U.S.C. \& 1403 (1976) (leases of civil aircratt must be recorded with F.A.A.); S.C. CODE ANN. 8 27-23-80 (Law. Co-op. 1976); see also Note, Mandarory Recording of Personal Property Leases in South Carolina: An Examination of the South Carolina Bailment Stature As Affected by U.C.C. Article Nine, 30 S.C. L. REv. 557 (1979). If the assignment of the lease and the reversion is for security, Article 9 would cover both aspects of the transaction.

191. See In re Western Leasing, Inc, 17 U.C.C. Rep. Serv. (Callaghan) 1369 (Bankr. D. Or. 1975) (sale of security chattel paper covering unotor vehicle perfected by possession, and title certificate registration not required to perfect rights in car against vendor's trustee in bankruptcy).

192. See In re Butter's Tire \& Battery Co., 17 U.C.C. Rep. Serv. (Callaghan) 1363 (Bankr. D. Or. 1975), $a f f d, 18$ U.C.C. Rep. Serv. (Callaghan) 1302 (D. Or. 1976) (purchaser of true lease and 
Unitary treatment could only be accorded in this situation by modifying non-Code law so that the transfer of the lease chattel paper would transfer the reversion thereby bringing the reversion under the scope of Article 9. This solution, however, might defeat the legitimate expectations of the purchaser of a leased car subject to a true lease. If the lease in the above example is soon to expire, the purchaser's primary concern is the car itself; it is the car and not the rentals that it purchases. Therefore, the sensible thing for the purchaser to do is to take whatever steps are usually necessary for a purchaser of a car to protect its interest in the car, such as changing the certificate of ownership. But if lease chattel paper is to be governed along with security chattel paper under Article 9, the purchaser's rights to the car would be tied up in the chattel paper because the car is subject to a lease, which the purchaser must take into its possession lest it risk losing its claim to the leased goods. Purchasers of items subject to short terin leases are apt to be unsophisticated purchasers. To subject them to a rule of perfection in the financing area may defeat their legitimate expectations, and the benefits of unitary treatment do not seem to outweigh the burdens that might be imposed on innocent parties. Therefore, although the exclusion of a transfer of the lessor's reversionary interest fron Article 9 coverage requires a distinction between leases and security agreements-including disguised conditional sales agreements-on the finance level, it is better to respect this bifurcation than to remedy it.

(b) Creation and perfection of security interests. If a lessor assigns both the lease and its ownership interest in the leased collateral, whether the assignment satisfies the requirements for creatimg a security interest under section 9-203, and for perfecting that security interest, may depend on whether the "lease" is a true lease or a disguised conditional sale. This bifurcation of the unitary treatinent of lease and security chattel paper cannot be reinedied without substantially modifying the legitimate expectations of the parties.

To create a security interest under section 9-203(1)(a), there niust be a signed agreeinent describing the collateral, or the collateral must be in the possession of the secured party. ${ }^{193}$ If a lessor executes a written assignment giving a financer a security interest in a true lease, and the financer proinptly perfects by filing a financing stateinent listing "the lease" as collateral, under non-Code law the assignment evidences the lessor's intent to transfer the rentals and the lease covenants, but

reversion, who obtained certificate of title registration covering motor vehicle, was properly protected).

193. U.C.C. § 9-203(1)(a). 
not the reversion. 194 Therefore, if the parties intended the reversion to be collateral as well, the written assignment, and the financing statement, ought to describe both the reversion and the lease. Similarly, if the lessor does not execute a written assignment but transfers possession of the lease document to the financer, the transfer indicates under non-Code law that the lessor intends to assign the rentals and covenants, and no more. A separate act would be required to transfer the reversion. Moreover, if separate acts are necessary to transfer the rentals and the reversion, then separate acts should similarly be required to perfect that transfer.

An analysis of the lessor's various rights and interests in Code-terminology yields the same result. The lessor's right to rentals under a written true lease qualifies as chattel paper ${ }^{195}$ when it is transferred. A security interest in chattel paper may be created by a security agreement or by transfer of the lease doeument, 196 and perfected by filing or by possession of the chattel paper. ${ }^{197}$ By contrast, the lessor's reversionary interest is an interest in goods. ${ }^{198}$ Because the goods are in the lessee's possession and the lease does not embody the lessor's reversionary interest, a security interest in the reversion must be created by a signed agreement ${ }^{199}$ and must be perfected by filing. Thus, separate acts are again required to create and perfect a security interest in the lessor's right to rentals and in the reversion, respectively. ${ }^{200}$ Therefore,

194. Vadner v. Rozzelle, 88 Utah 162, 167, 45 P.2d 561, 563 (1935) (lease assignment assigns rents, not title).

195. If there is no writing, the right to rentals is an account. See U.C.C. 8 9-106; see also supra notes $96-99$ and accompanying text. If there is a writing, it is considered chattel paper, and perfection in the right to rentals can only be achieved by perfection of an interest in the chattel paper, see Clark, Abstract Rights, supra note 107, at 463-64; a filing that covers accounts receivable will be insufficient, See In re Upstate Tanks, Inc., 30 U.C.C. Rep. Serv. (Callaghan) 1700 (Bankr. W.D.N.Y. 1981).

196. U.C.C. \& 9-105(i)(1) and comment 4; see id. \& 9-203(i); supra notes 124-30 and accompanying text.

197. See U.C.C. 88 9-304(1)(perfection by permissive filing), 9-305 (perfection by possession).

198. It is arguable that the reversion is a general intangible under U.C.C. 8 9-106 because it is incapable of present possession and represents primarily future rights contingent on termination of the lease. See, eg., Estate of Cook, 64 Cal. App.3d 852, 135 Cal. Rptr. 96 (1976) (assignment of legacy is general intangible). The reversion is distinguishable from a general intangible, however, because the lessor has present legal title to the goods even though it cannot possess them. It is this present interest, combined with the right to future possession, that is the collateral when the lessor gives a security interest in its reversion. See In re Leasing Consultants, Inc., 486 F.2d 367, 372 (2d Cir. 1973); In re Watertown Tractor Equip. Co., 94 Wis.2d 622, 289 N.W.2d 288 (1980).

199. See U.C.C. 8 9-203(1)(a).

200. Transfer of the lease may also transfer ancillary covenants such as the lessor's right to repossess the goods at defaule. See supra notes $43-47$ and accompanying text. These rights represent raw powers that fall under the catchall definition of a general intangible. It is arguable that because one cannot take possession of a gerieral intangible a security interest in the ancillary covenants can be perfected only by filing as to the general intangibles. Under this approach, three 
under non-Code law and under a Code analysis of the lessor's rights, a dual creation and perfection scheme emerges when the lessor under a true lease transfers both the lease and the reversion.

If, however, the "lease" were a disguised conditional sale, single acts would suffice to create and then to perfect a security interest in this type of chattel paper. Security chattel paper embodies the rights it represents, which include both the right to the income stream and the right to the goods, that is, the security interest. Because these rights are inherent in the paper, the creation and perfection of a security interest in the income stream and goods is achieved by single acts of creating and perfecting a security interest in the paper itself. 201

distinct acts of perfection would be required if the lessor conveys a security interest in all of its rights in the leased goods: perfection of a security interest in the rentals by possession of the lease; perfection of a security interest in the reversion by filing where the goods are located, see U.C.C. 8 9-103(1)(b); and perfection of a security interest in the ancillary covenants by filing where the debtor/lessee is located, see id \& 9-103(3)(b) \& (d).

According to the official comments to section 9-106 however, to the extent that these raw powers are ancillary either to the right to rentals or to the reversionary interest, perfection of a security interest in the rentals or in the reversionary interest operates to perfect a security interest in those ancillary rights. Consequently, at most only two perfecting acts are required: one as to the goods themselves and one as to the rentals in the form of lease chattel paper.

Note that some covenants may be independent of, rather than auxillary to, the rents or the reversion. It is possible that separate perfection of a security interest in such rights would be necessary. See, e.g. , Flemington Nat'1 Bank \& Trust Co. v. Domler Leasing Corp., 65 A.D.2d 29, 410 N.Y.S.2d 75 (1978) (assignment of lease from first chattel paper financer to second did not transfer rights under repurchase agreements executed at later time); see also in re Rogers, 30 U.C.C. Rep. Serv. (Callaghan) 1129 (Bankr. S.D. Iowa 1980) (auto financer did not have security interest in extended warranty charge). If such covenants are embodied in the lease document, however, it is arguable a security interest in them would be perfected by perfection of a security interest in the lease chattel paper.

201. It has been observed that courts and cominentators never question the single perfection rule for security leases under the Code. See Note, In re Leasing Consultants, Inc.: The Double Perfection Rule for Security Assignments of True Leases, 84 YALE L.J. 1722, 1729 n.45 (1975); see also In re Leasing Consultants, Inc., 486 F.2d 367 (2d Cir. 1973); Levie, supra note 18, at \& 28.04. This simple acceptance inay prevail because the scheme is unquestionable; "everyone thinks of [an assignment by a conditional seller disguised as a lessor] as including both the obligations secured and the security interest in the collateral." Clark, Banker's Guide, supra note 50, at 238. The single perfection rule follows from the general rule that the assignment of a debt transfers the security on the debt. See also Clark, Abstract Rights, supre note 107, at 464 (it is "practically necessary" to say that perfection as to goods is achieved by perfection as to the chattel paper). The scheme is consistent with pre-Code law, see supra notes 45-47, and with section 9-105(1)(b), which states that chattel paper evidences the security interest (but not that it evidences the reversionary interest of a true lessor). See also Epstein, Security Transfers by Secured Parties, 4 GA. L. REV. 527,540 (1970) (under Code, transfer of note transfers security; transfer of security alone of no effect.

One commentator has recently argued that the single perfection rule as to security leases is wrong. See Gutterman, supra note 80, at 352. Mr. Gutterman first points out that section 9. $306(5)$ (d) requires a security lease chattel paper financer to perfect directly in the goods themselves (without the benefit of any protection by perfection in the chattel paper) if the goods are returned or repossessed. This requirement, however, is limited to returned or repossessed goods and is a 
The first case to articulate the dual perfection rule for lease chattel paper, as opposed to the single perfection rule for security chattel paper, was In re Leasing Consultants, Inc. ${ }^{202}$ The parties to the true lease in that case clearly intended to transfer the reversion, and they had coinphed with the requirements of section 9-203. The only issue was whether the secured party's possession of the lease, and its filing against it, perfected its interest in the reversion. The Court of Appeals for the Second Circuit, affirming the court below, concluded that the lease chattel paper did not enbody the reversion and that perfection as to the paper would not perfect an interest in the reversion.

The dual perfection rule for true lease chattel paper as articulated in In re Leasing has been criticized on the grounds that it conflicts with the technical provisions and the policy of the Code. ${ }^{203}$ The technical objections are that there is no basis in the Code for distinguishing between true and security leases on the finance level204 and that the definition of chattel paper in section 9-105(1)(b) requires a definition of a lease that includes the reversion. The failure of the Code to distinguish between true and security leases in the chattel paper definition, however, is irrelevant to the extent that non-Code law is used to interpret its provisions. ${ }^{205}$ The essential question here is whether specific Code provisions or Code policy preclude rehance on this non-Code law. The language of section 9-105(1)(b) provides no such basis for departing froin non-Code law, and totally eliminating the distinction between lease and security chattel paper. It has also been argued that unless the requirement in section $9-105(1)(b)$ that the chattel paper include a

specific application of the perfection requirements in section 9-306(3)(c). Most cases arise prior to any return or repossession, and the perfection of a security interest in the clattel paper operates to perfect a security interest in the goods themselves. See Clark, Banker's Guide, supra note 50, at 227. Mr. Gutterman further argues that filing against the goods at the outset is preferable because it saves the financer the trouble of policing the debtor and reperfecting on return or repossession. To say that filing at the outset is preferable as a practical matter hardly denonstrates that it is required as a matter of law.

202. 351 F. Supp. 1390 (E.D.N.Y. 1972), remanded for evidentiary hearing, 486 F.2d 367 (2d Cir. 1973).

203. See Gutterman, supra note 80, at 352; Note, supra note 201, at 1727-33.

204. The distinctions in U.C.C. $81-201$ (37) have been dismissed as irrelevant and imapplicable at the finance level. See Note, supra note 201. The same commentator argues that in section 1201(37) the drafters viewed chattel mortgages as title retention devices, which would mandate double perfection for both security leases and true leases. Id. There are several logical flaws in this argument, which ultimately places too much weight on a definitional section which was not the responsibility of the Article 9 drafters and advisors. Coogan, supra note 10, at 922 . For a discussion of the problems inherent in a double perfection rule for security chattel paper, sec infra note 215.

205. See supra note 19. 
"lease"206 is read to encompass the reversion, the term is redundant because the requirement that there be a "monetary obligation" already includes the rentals and ancillary covenants. ${ }^{207}$ The fallacy in this argument is that the term "lease," like the term "security agreement," 208 is a limitation on, rather than an addition to, the phrase "monetary obligation." The effect of those terms is to limit the generabity of the phrase "monetary obligation"; only those monetary obligations arising from leases or security agreements are included in the definition of chattel paper.

The strongest arguinent in favor of a single perfection rule for true leases is the policy argument that Article 9 favors uniformity and prefers distinctions based on functional rather than formal lines. Often, assignees of lease chattel paper cannot be certain at the time of the assignment whether a lease will be treated by a court as a true lease or as a security lease. ${ }^{209}$ If the term "lease" in the definition, of chattel paper meant the rentals plus the reversionary interest, it would make the treatment of true leases and security leases parallel because the lease would then represent an interest in goods. ${ }^{210}$ This would eliminate the difficulty of distinguishing true leases froin disguised conditional sales on the finance level. This radical departure from non-Code principles, however, would make it unclear what interests were transferred in a particular transaction, ${ }^{211}$ and would make it impossible to transfer the lease without transferring the lessor's reversionary interest. 212

Furthermore, the public policy behind the filing system dictates that a lease chattel paper financer file separately as to its interest, if any, in the reversion. If a third party checks the financing statements for the

206. U.C.C. § 9-105(1)(b) states that "chattel paper" evidences "both a monetary obligation and a security imterest in or lease of specific goods. . .."

207. Note, supra note 201, at 1730 . This commentator relies on comments to U.C.C. \& 9-106 that were part of the 1972 amendinents to article 9 and were not in effect in New York when In re Leasing was decided. See 1977 N.Y. Law 866 (McKinney 1977) (effective July 2, 1978). Thus it is arguable that there was no redundancy in section 9-105(1)(b) when In re Leasing articulated the dual perfection rule. Furthermore, it is unlikely that the drafters imtended by some subtle distinction in the definition of chattel paper to radically change the definition of a lease under pre-Code law.

208. It is arguable that the requirement of a security agreenent is also redundant, because the transfer of a monetary obligation transfers by law any security for that obligation.

209. If there is any doubt as to the possible treatment of the paper, the assignee may be constrained to file everywhere against everyone concerning everything. This uncertainty places great burdens on the lender. See Clark, Banker's Guide, supra note 50, at 240 (detailing at least four places for fling).

210. See supra text accompanying notes 166-68.

211. See supra notes 167-72 and accompanying text.

212. See-supra note 168 and accompanying text. 
area in which the leased equipment is located, the records should alert the third party that the lessor may have transferred its ownership interest in the leased goods. If the lease is a disguised conditional sale, the "lessor" will file as to the "leased" goods in order to protect its security interest in them. On the finance level, the security chattel paper financer may or 'nay not file when the "lessor" transfers its security interest to the financer, but a third party can still determine from the records that the "lessor" no longer has an ownership interest in the leased goods. If the lease is a true lease, however, the lessor inay have made no filing. ${ }^{213}$ Therefore, if the lessor subsequently transfers to a financer its reversion as well as its rights under the lease, and if the financer was not required to file in order to perfect its interest in the reversion, a third party searching the records would find no indication that the lessor no longer owns the leased goods. A filing by the lease chattel paper financer as to the reversion will indicate that the lessor no longer retains its reversion, and the absence of a filing as to the rever-. sion should indicate that the lessor retains title to the goods. To maintain the integrity of the filing system, third parties should be able to rely on such indications. 214

For these reasons, the principle of unitary treatınent for all leases must yield in the area of creation and perfection of security interests. Security chattel paper financers need perfect only once, but true lease chattel paper is subject to a dual perfection rule.21s Any financer uncertain whether a particular "lease" is a true lease or a security lease should require the transferor to assign both the "lease" and the transferor's right and title to the goods, and then perfect as to both. The

213. Even if the lessor permissively files under section $9-408$, the creditors who check financing statements will only discover the existence of the leasehold. They will not be able to discover whether the lessor's retained ownership interest has been transferred.

214. Arguably, if there were a single perfection rule for lease chattel paper, third parties would realize that they must inquire as to the possible existence of chattel paper covering the goods and transferring the lessor's reversion. This would undermine the filing system by elevating the paperization principle over the recording principle. See Clark, Abstract Rights, supra note 107.

215. Alternatively, the Code could provide for unitary treaunent by mandating a dual creation and perfection rule for both security leases and true leases. This new rule would require modification of the non-Code principle that an assignment of the debt carries with it an assignment of the security. See 4 A. Corbin, supra note 32, \& 970; 2 S. Willuston, The LAw of Contracts 1044 (1920); see also 1 RESTATEMENT OF THE LAW OF SECURITY \& 29 (1941); Epstein, Security Transfers by Secured Parties, 4 GA. L. REv. 527 (1970). The rule would require separate assignments for the security interest and for the monetary obligation represented by the security chattel paper, the seeurity chattel paper assignee would be required to perfect separately as to the monetary obligation (by filing or by possession of the chattel paper) and as to the security interest (by filing).

The problem with this approach is that more financing is based on security chattel paper than on lease chattel paper, and the burden of double perfection for security chattel paper financers would therefore outweight the benefits flowing from total unitary treatunent of all leases. 
legitimate expectations of the parties can be protected only be rejecting unitary treatment in this area.

\section{Conclusion}

In its treatment of chattel paper, the Code attempts to give unitary treatment to true and security leases even though under non-Code law true leases lack many of the attributes that would justify their treatment as quasi-negotiable commercial specialties. ${ }^{216}$ The Code's chattel paper rules demonstrate the extent to which unitary treatment is possible. These rules have made it unnecessary im many instances to make the difficult distimction between true and security leases on the finance level, thus demonstrating the feasibility and desirability of unitary treatment.

The Code, however, also demonstrates the limitations of unitary treatment. In several respects the Code bifurcates the unitary scheine and allows the distinction between leases and security agreements, including disguised conditional sales agreements, to re-emerge on the finance level. In some instances the bifurcations are minor ones, due to drafting oversight, that can be remedied by liberal construction or by an amendment of the literal language. ${ }^{217}$ In other instances, the bifurcations are major ones that reflect the inherent differences between true leases and security leases. It would be impossible to remedy these major bifucations and give completely unitary treatment to lease and security chattel paper without drastically thwarting the expectations of the parties to the financing transaction. ${ }^{218}$ In such instances, the policy of protecting the legitimate expectations of the parties outweighs the policy of uniformity of treatment, and the latter must give way. As Oliver Wendell Holmes observed, "the truth is, that the law is always approaching, and never reaching, consistency."219 And that is as it should be.

216. See supra text following note 73.

217. See supra notes $108-62$ and accompanying text.

218. See supra notes 162-215 and accompanying text.

219. O. W. Holmes, THE COMmon LAW 36 (1923). Or in more prosaic terms: "A foolish consistency is the hobgoblin of little minds, adored by little statesmen and philosophers and divines." Emerson, Self Reliance, in 1 The Works of Ralph Waldo Emerson: Essays and REPRESENTATIVE MEN 30 (1919). 